University of Tulsa College of Law

TU Law Digital Commons

Articles, Chapters in Books and Other Contributions to Scholarly Works

2010

\title{
Does Gender Influence Attitudes Toward Copyright in the Filk Community?
}

Robert Spoo

Melissa Tatum

Follow this and additional works at: http://digitalcommons.law.utulsa.edu/fac_pub

Part of the Law Commons

\section{Recommended Citation}

18 Am. U. J. Gender Soc. Pol'y \& L. 219 (2010).

This Article is brought to you for free and open access by TU Law Digital Commons. It has been accepted for inclusion in Articles, Chapters in Books and Other Contributions to Scholarly Works by an authorized administrator of TU Law Digital Commons. For more information, please contact daniel-bell@utulsa.edu. 


\title{
DOES GENDER INFLUENCE ATTITUDES TOWARD COPYRIGHT IN THE FILK COMMUNITY?
}

\author{
MELISSA L. TATUM* \\ DR. ROBERT SPOO ${ }^{\dagger}$ \\ BENJAMIN POPE ${ }^{\ddagger}$
}

I. Filk and the Filk Community ...........................................................220

A. The Origins of the Filk Movement .........................................220

B. Intellectual Property Implications of Filk Creations ...................223

II. Intellectual Property Issues in Filk......................................................229

A. Copyright for Songs...............................................................229

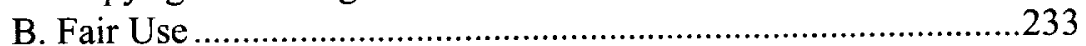

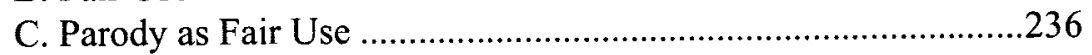

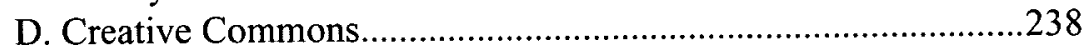

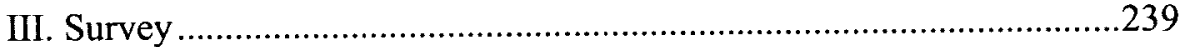

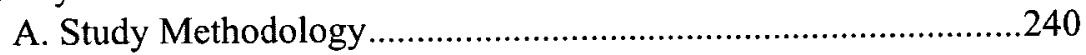

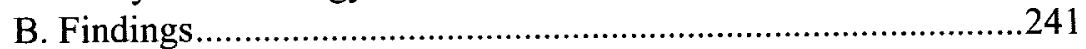

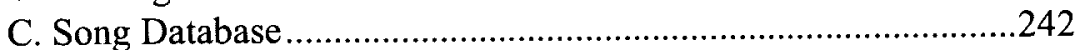

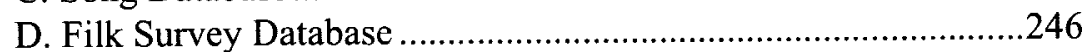

E. Basic Background.....................................................................246

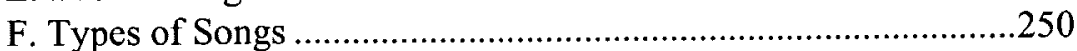

G. Understanding of Copyright and Intellectual Property Law ......250

H. Attitudes and Approaches to Copyright and Intellectual

Property Law ……………………………………..............253

IV. Conclusion.

\footnotetext{
* Research Professor of Law and Associate Director, Indigenous Peoples Law and Policy Program, University of Arizona James E. Rogers College of Law. Tatum is also a member of the filk community, with several published songs to her credit. The authors would like to thank the organizers of American University's Sixth Annual Conference on IP/Gender: Mapping the Connections, whose call for papers sparked this article, as well as the members of the filk community for sharing their thoughts and comments.

t Associate Professor, University of Tulsa College of Law; B.A. Lawrence University; M.A., Ph.D. Princeton University; J.D. Yale University.

‡ Graduate Student, University of Arizona's Graduate Interdisciplinary Program in Statistics.
} 
If you are reading this article, you likely either already know what the filk community is and are wondering why it is mentioned in a law review article or you are mentally asking "the WHAT community?" and are wondering whether something went dreadfully wrong at the copyedit stage. "Filk" is the term used to describe the music of the science fiction community, and "filkers" are the members of the filk community and are most commonly found participating in song circles at science fiction conventions.

Over the past twenty years, the filk community has expanded from a small group of science fiction convention-goers who occupied unused convention rooms during late night hours to a community large enough to organize several dedicated filk conventions each year, a Hall of Fame, and an annual awards ceremony. Although some performers in filk circles may sing traditional folk songs, it is much more common to hear "filk songs" at such gatherings. Filk songs are a specialized genre and span a wide spectrum. While many filk songs are original lyrics set to original music, many more filk songs consist of lyrics written to existing music and/or lyrics based on characters or worlds created by other people. These practices can potentially impinge on existing intellectual property law protections and thus provide a vehicle for exploring the intersection of intellectual property, community-based norms, and gender. This article explores the intellectual property issues implicated by filk and, through two empirical databases, inquires whether a filker's gender influences his or her attitude towards intellectual property law.

Part I begins by setting out a more detailed explanation of filk, including a brief history as well as examples of different types of filk songs. Part II examines the relationship between filk and intellectual property law. Part III, the centerpiece of the article, explores the question asked in the title of this article by discussing the study's methodology, the two databases we created, and the various statistical results generated from those databases.

\section{FILK AND THE FILK COMMUNITY}

\section{A. The Origins of the Filk Movement}

The science fiction and fantasy community is unique in several respects. It is perhaps the only fiction genre that regularly brings authors and fans together, usually for weekend conventions, also known as "cons." For the uninitiated, two basic types of science fiction conventions exist-media conventions and literary conventions. Media conventions are those whose main guests are actors from various movies and television shows. Literary conventions are those whose main guests are the authors who write short stories and novels. Our focus here is on literary conventions, which have 
existed for decades and which come in all shapes and sizes, ranging from the small local cons bringing together local authors and fans, to regional cons drawing several hundred attendees (and usually 50-100 writers of varying levels of fame), to the World Science Fiction convention, an annual event attracting hundreds of authors and thousands of fans.

For a variety of reasons, it emerged that an overlap existed between literary science fiction convention-goers and musicians of various skill levels. These musicians and music-lovers began assembling in the evening after formal convention programming ended to share their music and hold song circles. ${ }^{1}$ Since many were writers, they began writing lyrics, and the genre of filk emerged as a distinct form of music. It is difficult to define "filk" with any accuracy, except to say it is the music of the science fiction and fantasy community. Perhaps one of the better definitions was offered by Gary McGath, who states that "filk music is a musical movement among fans of science fiction and fantasy fandom and closely related activities, emphasizing content which is related to the genre or its fans, and promoting broad participation. Filkers are people who participate in this movement."2

The term "filk" is often traced back to a typographical error made by Lee Jacobs, an author for the Spectator Amateur Press Society, who typed "filk music" instead of "folk music" in an article. ${ }^{3}$ Credit for popularizing the term is usually given to Karen Anderson, and while that may explain the origins of the term, it does not clarify what it means. ${ }^{4}$ Since filk is all about music, we'll start with a musical explanation, written in one particular style of filk -one that borrows an existing song, discards the original lyrics and writes new, often satirical, lyrics. This song is called (fittingly) What Is This Thing Called Filk $?^{5}$ and is sung to the tune of The Battle Hymn of the Republic: ${ }^{6}$

1. See Jordin Kare, Filk Music?, SINGOUT MAGAZINE, 1995, available at http://www.interfilk.org/interfilk/singout.htm\#Jordin Kare.

2. Gary McGath, Filk: A New Definition, May 13, 2002, http://www.mcgath. $\mathrm{com} /$ filkdef.html (last visited Sept. 22, 2009).

3. See Jan Mailander et al., Filking 101: The Folk Music of Science Fiction, http://www.filk.com/filk101.htm (last visited Sept. 22, 2009) (arguing that despite other urban legends, the term "filk" evolved from Jacobs's error in his unpublished article, "The Influence of Science Fiction on Modern American Filk Music").

4. Lee Gold, Tracking Down the First Deliberate Use of "Filk Song," $\mathrm{http}: / / \mathrm{ww} w$.nightsong.com/filk/twippledop.

5. Lyrics by Melissa Tatum, available at http://meltatum.wordpress.com. The title What Is This Thing Called Filk? is itself a playful allusion to works like Cole Porter's What Is This Thing Called Love? (1929) and Louie Armstrong's What Is This Thing Called Swing? (1939).

6. The Battle Hymn of the Republic was written by Julia Ward Howe and was published in ATLANTIC MONTHLY in February 1862; the song is set to a tune written around 1855 by William Steffe. It is not clear whether Steffe registered a copyright in the tune, but even if he did, it would likely have expired by 1900 , and the tune would then have entered the public domain. See Act of Feb. 3, 1831, ch. $16 \S \S 1-2,4$ Stat. 
My flight was cancelled; I was stuck in town another night.

When I showed up at the hotel, you would not believe the sight.

I saw Vulcans strumming guitars but the words did not sound right.

I heard them call it filk.

\section{CHORUS:}

I'm confused, did you say "filking"?

Sorry, did you say a "filk" song?

I have never heard of such a thing.

What is this thing called filk?

A filk song sometimes starts by taking favorite melodies

Then it substitutes new lyrics with exquisite irony

The resulting song sounds something like a Weird $\mathrm{Al}$ parody ${ }^{7}$

Voila - a new filk song!

A filk song sometimes borrows from a favorite universe; Spins a story of adventure and a shore leave quite perverse Sets their exploits to new music, shows just why there's no recourse They're Banned from that Argo! ${ }^{8}$

A filk song sometimes starts by penning lyrics fresh and new and they tell us the sad story of the Easthill Mining Crew ${ }^{9}$ The composer writes new music to accompany the mood That's also part of filk!

Filk happens in two primary locations-at cons themselves and at socalled "house filks." At conventions, filk has grown from a surreptitious

436 (granting copyrightable works an original term and a renewal term totaling fortytwo years).

7. Weird Al Yankovic is an American singer-songwriter known for his parodies of hit songs. See, e.g., WEIRD AL YANKovic, Eat it, on EAT IT (Scotti Bros. 1984) (parodying MICHAEL JACKSON, Beat It, on THRILLER (Epic 1982); WEIRD AL YANKovic, The Saga Begins, on RUNNING WITH ScISSORS (Volcano Records 1999) (parodying Don McLean's American Pie).

8. Banned From Argo is perhaps the most famous (or infamous) filk song of all time; it received the 2003 Pegasus Award for Best Classic Filk Song. See Leslie Fish, Banned from Argo (1977), available at http://ovff.org/pegasus/songs/banned-fromargo.html (describing what the characters from the original Star Trek series did while on shore to get them banned from Argo Port, set to a traditional tune called Boston Burglar).

9. See Brooke Lunderville, The Wreck of the Crash of the Easthill Mining Disaster, http://catfish.dhs.org/ happyfish/filk/wreckcrashetc.html (last visited Sept. 25,2009 ) (documenting the death of the Easthill Mine crew and receiving the 2009 Pegasus Award for Best Filk Song). 
activity in hallways and hotel rooms to the subject of dedicated panels at conventions. ${ }^{10}$ Several annual conventions are completely devoted to filk, ${ }^{11}$ and there exists both an annual awards ceremony ${ }^{12}$ and a Hall of Fame. ${ }^{13}$ Filk is an international phenomenon, with devotees in the United States, Canada, the United Kingdom, Germany, and scattered throughout other countries. Where a concentration of filkers exists, one will also find "house filks"-basically, parties at someone's house where the focus is on a filk song circle and sharing the music. ${ }^{14}$

\section{B. Intellectual Property Implications of Filk Creations}

The location, protocols, and ethos of filk all play a part in the development of filkers' attitudes toward intellectual property. Traditionally, filk rooms are arranged in circles, where the performers each take turns and those who are present simply to listen are scattered around the room behind the performers. The method of taking turns can vary, with the two basic forms being the bardic circle and chaos. ${ }^{15}$ In a bardic circle, the turn proceeds in order around the circle, with each person either performing a single song or passing the turn without singing. ${ }^{16}$ In a chaos circle, the turn proceeds randomly around the circle, with the general presumption that each song should be connected in some way (by tune, theme, composer, etc.) to the song that was just performed. ${ }^{17}$ Both have advantages and disadvantages, and several variations have developed in an effort to maximize the advantages and minimize the disadvantages. In addition, as filk has become more popular, conventions have also begun offering filk in the form of concerts featuring top performers.

Since filk primarily happens in these informal song circles, the question arises as to whether filk is transmitted or shared beyond those present at the

10. See Kare, supra note 1 (demonstrating the growth of filk by listing the wellknown authors who have become filkers and denoting the inclusion of filk at the annual World Science Fiction Convention).

11. See, e.g., GAFilk, GAFilk Home Page, http://www.gafilk.org (last visited Sept. 21,2009 ) (a regional filk convention in Atlanta, Georgia); OVFF, Ohio Valley Filk Fest 25, http://www.ovff.org (last visited Sept. 21, 2009) (a regional filk convention in Dublin, Ohio).

12. OVFF, Pegasus Awards, http://ovff.org/pegasus (last visited Sept. 17 2009) (awarding Pegasus Awards in categories such as Best Filk Song).

13. Filk Hall of Fame, http://www.filkontario.ca/hof/hofmain.html (last visited Sept. 22, 2009) (honoring performers, organizers, facilitators, or people who have contributed to the growth of filk; the induction ceremony is part of the FilkONtario convention).

14. See Jan Mailander, Filk 101: What Is a House Filk? http://www.filk.com/ filk101_3.htm (last visited Sept. 22, 2009).

15. See Kare, supra note 1.

16. See id.

17. See id. 
performance itself. ${ }^{18}$ Filk music is shared in a number of ways, from informal swapping of recordings made of the song circle to professional quality CDs. ${ }^{19}$ The songs themselves are also shared through websites (containing recordings, lyrics, and/or actual lead sheets ${ }^{20}$ ), through songbooks or filk magazines, or simply by someone asking for a copy at a circle after a song is performed. It is fairly common for filkers to arrive at a song circle with several binders of photocopied paper containing song lyrics, although that is increasingly being replaced by a laptop and a computerized database. ${ }^{21}$

Filk songs themselves come in many varieties. Some use original lyrics, and some use lyrics based on characters and universes created by other people. Some filkers compose original tunes, some use tunes that are in the public domain, some use tunes that are under copyright by other persons, and some use tunes written by other filkers. A list of the various combinations of lyrics and melodies demonstrates that eight basic permutations of filk songs exist:

1) Original lyrics to an original melody;

2) Original lyrics to a traditional melody;

3) Original lyrics to a melody under copyright;

4) Original lyrics to a melody composed by another filker; ${ }^{22}$

5) Lyrics based on characters/universe created by another person ${ }^{23}$ and set to an original melody;

6) Lyrics based on characters/universe created by another person and set to a melody in the public domain;

\section{See id.}

19. See id. (sharing a history of filk publications, which were historically circulated by word of mouth and cassette recordings until 1980 when Off Centaur Recordings began producing songbooks and filk cassette tapes); see also FilkONtario, Filk Hall of Fame Inductee 1995: Off Centaur Recordings, http://www.filkontario.ca/hof/ inductees/offcentaur.html.

20. Lead sheets combine lyrics with chords, and may include the musical notation for a basic melody line, but do not include full musical notation.

21. This assertion is based on Melissa Tatum's personal experience and first-hand knowledge derived from years of participation in filk circles.

22. As a copyright matter, categories three and four could technically be folded together, because a filker who composes an original tune has just as much legal right to that tune as the person who composes a Top 40 hit. See 17 U.S.C. $\$ 201$ (a) (2006) (stating that a copyright arises upon completion of an original work and vests initially in the creator). We have chosen to separate the two, however, because filking another filker's song is the ultimate homage in the filk community. Compare Leslie Fish, Banned From Argo, http://www.ovff.org/pegasus/songs/banned-from-argo.html (last visited Sept. 17, 2009) (filking about Star Trek characters being banned from the Argo Port), with John Creasey et al., The Bastard Children of Argo (Random Factors 2001), http://www.massfilc.org/filkindex/bastardchildrenargo.xml (containing parodies such as "Banned from Armor").

23. Some filk songs take poems and set them to melodies. We have chosen to include those as "lyrics based on characters/universe created by another person" rather than create a separate category. 
7) Lyrics based on characters/universe created by another person and set to a melody under copyright by someone else; and

8) Lyrics based on characters/universe created by another person and set to a melody composed by another filker.

Understanding these permutations is important to understanding the intellectual property issues that arise in filk, so before turning to a discussion of those issues, we will set out brief examples to illustrate each permutation.

The first category, original lyrics to an original melody, is fairly straightforward and does not differ from any other song-someone composes an original tune and an original melody and either performs it in a filk circle and/or uses science fiction/fantasy elements as a central theme. These are often difficult to differentiate from any folk song. Indeed, Kathy Mar's Drink Up the River has been recorded by mainstream bands. ${ }^{24}$ Original filk songs range from the poignant, such as Leslie Fish's Hope Eyrie, ${ }^{25}$ paying tribute to the moon landing, to the witty, such as Brooke Lunderville's Wreck of the Crash of the Easthill Mining Disaster. ${ }^{26}$

The previously discussed musical explanation What Is this Thing Called Filk?, set to the Battle Hymn of the Republic, is an example of the second category, original lyrics set to a tune in the public domain. ${ }^{27}$ The third category consists of original lyrics written to a melody under copyright. An example is the song Callin' Baton Rouge, written by Dennis Linde and performed by Garth Brooks, which was transformed into Snippin' Off His Mail. Here is the first verse of the original song and the filk song:

\begin{tabular}{|c|c|}
\hline Callin' Baton Rouge & Snippin' Off His Mail $^{29}$ \\
\hline I spent last night in the arms & I spent last night in \\
\hline Of a girl in Louisiana & \\
\hline And though I'm out on the highway & he highway, \\
\hline My thoughts are still with her & my thoughts are still with him \\
\hline $\begin{array}{l}\text { Such a strange combination of a } \\
\text { woman and a child }\end{array}$ & $\begin{array}{l}\text { Such a strange combination of a } \\
\text { warrior and a man }\end{array}$ \\
\hline Such a strange situation stoppin' & such a strange situation stoppin' \\
\hline
\end{tabular}

24. Ohio Valley Filk Fest, The Pegasus Awards: Drink Up The River, http://www.ovff.org/pegasus/songs/drink-up-the-river.html (last visited Oct. 1, 2009).

25. Ohio Valley Filk Fest, The Pegasus Awards: Hope Eyrie, http://www.ovff.org/pegasus/songs/hope-eyrie.html (last visited Oct. 1, 2009).

26. See Lunderville, supra note 9.

27. Tatum, supra note 5.

28. The Official Garth Brooks Website, Callin' Baton Rouge (2006), http://www.garthbrooks.com/broadband.cfm (follow "Discography" hyperlink, then follow "In Pieces" hyperlink, then follow "Callin' Baton Rouge" hyperlink).

29. See app. A (containing complete filk song lyrics). 
every hundred miles

Callin' Baton Rouge every other kiss, snippin' off his mail.

The fourth type of filk song sets original lyrics to a melody composed by another filker. An example of this category is Melissa Tatum's Urban Legend, which uses the tune Brooke Lunderville composed for Wreck of the Crash of the Easthill Mining Disaster. Here are the first two verses of each as an illustration:

\begin{tabular}{|c|c|}
\hline Wreck of the Crash ${ }^{30}$ & Urban Legend $d^{31}$ \\
\hline $\begin{array}{l}\text { Let me tell you the story, as sad as } \\
\text { it's true } \\
\text { Of the } 17 \text { men of the Easthill Mine } \\
\text { crew } \\
\text { They were digging for copper for } \\
\text { telephone wires } \\
\text { When the pitshaft was blocked by a } \\
\text { terrible fire } \\
\text { Escape was cut off by the flames } \\
\text { and the ash } \\
\text { Yet they might have been rescued } \\
\text { but for that ship crash } \\
\text { Let me tell you the story, as sad as } \\
\text { it's true } \\
\text { Of the } 48 \text { sailors and the } 17 \text { men of } \\
\text { the Easthill Mine crew } \\
\text { The S.S. Kentucky was badly off } \\
\text { course } \\
\text { To've arrived in the tailing pond } \\
\text { instead of the port } \\
\text { She ran aground in the smoke at the } \\
\text { top of the mine } \\
\text { Which also obscured the rail } \\
\text { passenger line }\end{array}$ & $\begin{array}{l}\text { Let me tell you the story, and I } \\
\text { swear that it's true, } \\
\text { of the six drunken frat boys who } \\
\text { needed to pee } \\
\text { They were hazing new pledges out } \\
\text { near the train track, } \\
\text { so a bathroom was certainly } \\
\text { something they lacked } \\
\text { Their urine streams hit direct on the } \\
\text { third rail, } \\
\text { as they stood shocked \& buzzing the } \\
\text { train whistle wailed } \\
\text { Let me tell you the story, and I } \\
\text { swear that it's true, } \\
\text { of the newly flat penny and the six } \\
\text { drunken frat boys who needed to } \\
\text { pee } \\
\text { Two daring children were breaking } \\
\text { curfew, } \\
\text { so they could flatten their pennies } \\
\text { that were shiny \& new } \\
\text { the train hit the coins and without } \\
\text { warning it soared, } \\
\text { straight into the van with a family } \\
\text { on board }\end{array}$ \\
\hline
\end{tabular}

The fifth type of filk song consists of lyrics that use characters or a universe created by another person, but sets those lyrics to an original melody. One example of this category is Dr. Mary Crowell's Legolas,

30. Lunderville, supra note 9.

31. See app. A (containing complete filk song lyrics). 
which sings the praises of J.R.R. Tolkien's character as portrayed by Orlando Bloom: "I like to watch him on the silver screen / Built like I like 'em, he is long and lean / Yes, he is,/And I am his/ Gotta thing for an elf, can't help myself,/ O Legolas!"'32

Leslie Fish's Banned from Argo ${ }^{33}$ represents the sixth category of filk song. It uses the characters from the original Star Trek series (although it never actually names them) and employs a traditional tune called Boston Burglar:

When we pulled into Argo Port in need of R\&R,

The crew set out investigating every joint and bar.

We had high expectations of their hospitality,

But found too late it wasn't geared for spacers such as we.

\section{CHORUS:}

And we're banned from Argo, everyone.

Banned from Argo, just for having a little fun.

We spent a jolly shore leave there for just three days or four,

But Argo doesn't want us any more.

The Captain's tastes were simple, but his methods were complex.

We found him with five partners, each of a different world and sex.

The Shore Police were on the way-we had no second chance.

We beamed him up in the nick of time-and the remnants of his pants.

The seventh form of filk song uses lyrics based on the characters or universe another person has created and sets them to a copyrighted melody. An example is Paksenarrion, which is based on Elizabeth Moon's trilogy and uses Paul Simon's tune for Mrs. Robinson:

\begin{tabular}{|l|l|}
\hline Mrs. Robinson & Paksenarrion \\
\hline And here's to you, Mrs. Robinson, & Just look at you, Paksenarrion \\
Jesus loves you more than you will & lowly farm girl, now a paladin \\
know & touched by Gird \\
Whoa, whoa, whoa & He safeguards you, Paksenarrion \\
God bless you, please, Mrs. & as you wander answering his call \\
\hline
\end{tabular}

32. Ohio Valley Filk Fest, The Pegasus Awards: Legolas, http://www.ovff. org/pegasus/songs/legolas.html (last visited Sept. 17, 2009).

33. Fish, supra note 8.

34. Paul Simon, Mrs. Robinson, on Bookends (Columbia Records 1968), lyrics available at $\mathrm{http}: / / \mathrm{ww} w$.paulsimon.com/node/ 108 .

35. See app. A (containing complete filk song lyrics). 


\begin{tabular}{|l|l|}
\hline Robinson, & near and far, near and far \\
Heaven holds a place for those who & She dreams of armies, \\
pray & soldiering, adventures, \\
Hey hey hey, hey hey hey & so much more \\
We'd like to know & She hungers for a \\
A little bit about you & very different life \\
For our files. & Run away, Paks, you'll fulfill \\
We'd like to help you learn & those burning, questing dreams \\
To help yourself. & Start your life a-new, \\
Look around you. All you see & prepare to shed the old \\
Are sympathetic eyes. & \\
Stroll around the grounds & \\
Until you feel at home. & \\
\hline
\end{tabular}

The final category of filk song contains lyrics based on the characters or universe another person has created and sets them to a melody composed by another filker. An example is Daniel Reitman's Cetagandan Ale, which uses Lois McMaster Bujold's Vorkosigan series for the lyrics and sets them to the tune of Tom Smith's 307 Ale:

\begin{tabular}{|c|c|}
\hline $307 \mathrm{Ale}^{36}$ & Cetagandan $\mathrm{Ale}^{37}$ \\
\hline $\begin{array}{l}\text { There's many drinks you'll drink, } \\
\text { me lads, on every world that's new. }\end{array}$ & $\begin{array}{l}\text { There's many a spe } \\
\text { days for a Vor lord to }\end{array}$ \\
\hline There's Saurian Brandy, Cranapple & There's hot London \\
\hline $\begin{array}{l}\text { Schnapps, and a good old } \\
\text { Tullamore Don't. }\end{array}$ & $\begin{array}{l}\text { bugbutter schnapps, and that bad old } \\
\text { Kyril Isle Don't! }\end{array}$ \\
\hline $\begin{array}{l}\text { There's Busch and Beck and Bud } \\
\text { and Bock and others dark and pale, } \\
\text { But I think you'll find the finest } \\
\text { kind is Three-Oh-Seven Ale. } \\
\text { (chorus) }\end{array}$ & $\begin{array}{l}\text { There's maple mead and District red } \\
\text { and stuff to make you pale } \\
\text { But I think you'll find the worst of } \\
\text { all is Cetagandan ale } \\
\text { (chorus) }\end{array}$ \\
\hline $\begin{array}{l}\text { Three-Oh-Seven Ale, me lads, } \\
\text { Three-Oh-Seven Ale, }\end{array}$ & $\begin{array}{l}\text { Cetagandan ale, milord, Cetagandan } \\
\text { ale }\end{array}$ \\
\hline that any bar has & $\begin{array}{l}\text { little vintage that you won't } \\
\text { or sale }\end{array}$ \\
\hline waste, it'll make you fit & $\begin{array}{l}\text { Don't take your cha } \\
\text { or you know you're }\end{array}$ \\
\hline
\end{tabular}

36. Ohio Valley Filk Fest, The Pegasus Awards: 307 Ale (1989), http://www.ovff.org/pegasus/songs/307-ale.html.

37. Michael Bendari, More Bujold Filk-Part 7, June 8, 2002, http://www. dendarii.co.uk (follow "The Bujold Overflow Site" hyperlink; then follow "The Bujold Filk Archive" hyperlink; click on desired title). 
There's nothing that you'll ever There's nothing that you'll ever taste taste like Three-Oh-Seven Ale, me like Cetagandan ale lads, Three-Oh-Seven Ale.

In the next section, we explore some of the intellectual property issues filk raises and take a closer look at these categories.

\section{INTELLECTUAL PROPERTY ISSUES IN FILK}

\section{A. Copyright for Songs}

In the United States, as in many countries of the world, a copyright arises upon the completion of a work, or as the 1976 U.S. Copyright Act phrases it, when the work is "fixed in any tangible medium of expression." copyright in filk lyrics, for example, exists from the moment the filker writes down the lyrics on a piece of paper, saves them to a computer harddrive, records them on tape or a cell phone, or burns them to a CD. ${ }^{39}$ There is no need, as there once was under U.S. law, to publish the work with a proper copyright notice, or satisfy any other formalities, in order to own a copyright. $^{40}$ Only if the filker wants to enforce the copyright by means of a court action will the filker have to register the copyright with the U.S. Copyright Office. ${ }^{41}$

38. 17 U.S.C. $\S 102$ (a) (2006); see also 17 U.S.C. $\S 101$ (2006) (defining the term "fixed" as sufficiently permanent or stable to permit the work to be perceived, reproduced, or otherwise communicated for a period of more than transitory duration).

39. See $\S 102(a)$ (identifying musical works as works fixed in a medium of expression).

40. Under the previous U.S. Copyright Act, failure to include a proper copyright notice on publicly distributed copies of the work resulted in automatic injection of the work into the public domain. See Maljack Prods., Inc. v. UAV Corp., 964 F. Supp. 1416,1420 (C.D. Cal. 1997) (noting that the 1909 Act required proper notice for a work to secure statutory copyright protection). Compare Copyright Act of 1909, 17 U.S.C. $\S 10(1977)$ (stating that copyright is secured through publication of a work with a copyright notice), with Act to Implement the Berne Convention for the Protection of Library and Artistic Works, Pub. L. No. 100-568, 102 Stat. $2853 \S 7$ (1988) (eliminating affixation of a copyright notice to copies of a work as a condition of copyright protection under U.S. law, though certain permissive statutory benefits to including a notice were retained), and 17 U.S.C. $\S 401$ (a) (2006) (stating that a notice of copyright "may" be placed on publicly distributed copies of a work).

41. See 17 U.S.C. $\$ 411$ (a) (2006) (applying only to copyright actions brought in the United States; for works originating in other countries adhering to the Berne Convention for the Protection of Literary and Artistic Works, preregistration brings with it certain benefits but is not a prerequisite for instituting a copyright action in a U.S. court); see also 17 U.S.C. $\$ 412$ (2006) (preventing an award of statutory damages or attorney's fees if the infringement occurred before the date of an unpublished work's registration). 
Unless the work is created by an employee or an independent contractor as a "work made for hire," ${ }^{42}$ the copyright in the work vests initially in the person who originates and fixes the work. ${ }^{43}$ A filker who comes up with an original melody or lyrics is the sole owner of the copyright in that creation from the moment it is fixed in a tangible medium of expression. If two or more filkers collaborate on a work, however, the copyright in the work may be jointly owned by the collaborators, depending on the circumstances of creation. ${ }^{44}$ For example, a lyricist and a composer can enjoy separate copyrights in their respective contributions if they generated those contributions without any intention of being co-authors. However, if they produced their separately copyrightable contributions with the intention that these be merged into interdependent parts of a unitary whole, and if they both intended to be co-authors, then they will jointly own the copyright in the combined music and lyrics. ${ }^{45}$ If a copyright is jointly owned by two or more persons, any one joint owner may license the work without permission from the others, with the sole duty of accounting to the others for their pro rata share of profits. ${ }^{46}$

Co-authors can allocate shares of profits among themselves by contract, or they can contract away joint authorship altogether by providing that contributions to a song be separately owned. Litigation sometimes arises if someone claims a co-author role, and therefore joint authorship status, and the other author or authors deny intending a joint work or a co-author relationship. A famous example involved the composer of the Broadway musical, Rent. ${ }^{47}$ The composer brought in a "dramaturg" during production to make suggestions about the script and to liven up its plot, characters, and other elements. Later, the dramaturg claimed co-author status and a share of profits in the smash-hit play. The court held that it was clear from the composer's statements, contracts, work habits, and other evidence that he

42. See $\S 101$ (defining "work made for hire" as a work prepared by an employee within the scope of employment or as a work specially commissioned if the parties expressly agree in writing that the work will be considered a work made for hire); see also 17 U.S.C. $\S 201$ (b) (2006) (designating the employer or other person for whom the work was prepared as author of the work and as owner of all rights comprised in the copyright).

43. See $\S 201$ (a) (stating that the copyright originally vests with the creator).

44. See id. (stating that the authors of a joint work are co-owners of copyright in the work); see also $\S 101$ (defining "joint work" as "a work prepared by two or more authors with the intention that their contributions be merged into inseparable or interdependent parts of a unitary whole").

45. See § 201(c); Childress v. Taylor, 945 F.2d 500, 507-08 (2d Cir. 1991) (stating that a useful test is whether, absent contractual agreements concerning authorship, each contributor intended that every contributor would be identified as a co-author).

46. See Thomson v. Larson, 147 F.3d 195, 205 (2d Cir. 1998) (holding that a dramaturg was not a co-author because the playwright did not intend for her to be a coauthor).

47. See id. at 197-98. 
never intended to be a co-author with the dramaturg or anyone else; hence, his copyrighted material remained exclusively his own. ${ }^{48}$

Regardless of whether joint authorship exists, it is important to bear in mind that separate copyrights can exist in separate works. For example, the copyright in a filk melody might be entirely separate from the copyright in filk lyrics, or the copyright might exist in the music and lyrics combined. If the filker goes on to record the musical work (music and lyrics) on a CD, the resulting sound recording will enjoy a copyright that is separate from the copyright or copyrights in the underlying musical composition. ${ }^{49}$

When a recorded song has become a hit, others often want to record their own versions, or "covers," of the song. Under U.S. copyright law, imitators are able to do this lawfully without negotiating a license with the author of the underlying song, ${ }^{50}$ and without infringing any copyright in the initial sound recording based on the song. ${ }^{51}$ An imitator can produce a "cover" version of a previously recorded song without negotiating a license with the songwriter because section 115 of the U.S. Copyright Act provides for a "compulsory" or "mechanical" license in these circumstances. Once the owner of a song copyright has initially authorized a public distribution of the song (a "nondramatic musical work") on a vinyl record, tape, CD, or other medium, others can record that song as cover versions and distribute those versions on their own records, tapes, CDs, or other media (including digital transmissions) under the section 115 compulsory license provision, upon payment of a fixed license royalty fee. ${ }^{52}$ The license is "compulsory" because it cannot be refused by the owner of the song copyright as long as the user has complied with the notice requirements and other provisions of section 115. This is how the public is able to enjoy so many different versions of a hit song recording. The compulsory license requires that the user pay a certain fixed royalty per copy to the copyright owner, though the royalty is often determined by private contract instead. ${ }^{53}$

48. See $i d$. at 202-06 (determining that the composer retained decision-making authority, was billed as the sole author, and did not exhibit behavior that indicated he considered the dramaturg a co-author).

49. See 17 U.S.C. $\$ 102(a)$ (2006) (defining "musical works, including any accompanying words" as separate works from "sound recordings").

50. See 17 U.S.C. $\$ 115$ (a)(1) (2006) (allowing any person to obtain a compulsory license to make and distribute versions of the work).

51. See 17 U.S.C. $\$ 114$ (b) (2006) (extending the exclusive rights of a copyright owner to the "actual sounds" fixed in his or her sound recording, but not to a sound recording "that consists entirely of an independent fixation of other sounds, even though such sounds imitate or simulate those in the copyrighted sound recording").

52. See $\$ 115(\mathrm{c})(3)$ (fixing royalty fees).

53. See 24/7 Records, Inc. v. Sony Music Entm't, Inc., 429 F.3d 39, 42 (2d Cir. 2005) (distinguishing between a negotiated mechanical license, which the copyright owner is free to grant or deny, and a compulsory license, which allows the imitator to create a cover without consent when the copyright owner is given notice and paid 
The compulsory license for cover versions might be of only limited use to filkers. First, a filker could avail herself of a section 115 compulsory license only if she planned public distribution of recorded copies of her version of a previously recorded song. ${ }^{54}$ The compulsory license would not apply to public performances of the filker's new version, which are the means filkers most frequently use to offer their creations to the public. ${ }^{55}$

Second, a section 115 compulsory license "includes the privilege of making a musical arrangement of the work to the extent necessary to conform it to the style or manner of interpretation of the performance involved, but the arrangement shall not change the basic melody or fundamental character of the work, and shall not be subject to protection as a derivative work under this title, except with the express consent of the copyright owner." ${ }^{96}$ This provision allows an imitator to cover a previous recording by creating a new musical arrangement that will accommodate the imitator's style or manner of interpretation. For example, if the Vienna Boys' Choir wished to make a cover recording of I've Gotta Be Me (the song Sammy Davis, Jr. and others made famous), changes to the song necessary for adapting it to the style and manner of a male chorus would be permissible under section $115 .^{57}$

But the "style or manner" exemption under section 115 has its limits. It does not apply to an arrangement that "change[s] the basic melody or fundamental character" of the original song or to anything that could be regarded as a derivative work adaptation of the song. ${ }^{58}$ Because filkers, by definition, change some portion of the underlying song in a fundamental way-typically the lyrics-it is doubtful that filkers could often successfully invoke the section 115 compulsory license to shield unauthorized distributions of their performances on CDs or other media. ${ }^{59}$ More likely than not, the creative adaptations produced by filkers would be regarded as unauthorized derivative works based on the original songs,

royalties).

54. See $\S 115(\mathrm{a})(1)$ (requiring the compulsory license holder's primary purpose to be the distribution of the work to the public for private use).

55. But see 17 U.S.C. $\S 110(4)$ (2006) (stating that if a public performance is for nonprofit purposes, the performance is exempt from copyright infringement).

56. $\S 115(a)(2)$.

57. Oldielyrics.com, I've Gotta $\mathrm{Be} \mathrm{Me}$, http://www.oldielyrics.com/lyrics /sammy_davis_jr/ive_gotta_be me.html (last visited Oct. 3, 2009); see also § 115(a)(2) (stating that a compulsory Ticense includes changing the "style or manner of interpretation" of the performance, so the work's alteration from one singer to multiple singers is included in a compulsory license).

58. $\S 115(\mathrm{a})(2)$.

59. See Mailander, supra note 3 (giving examples of filk as known songs with new lyrics, which would alter the nature of the work such that it would no longer be fall under section 115 protections). 
requiring the "express consent of the copyright owner."

The law concerning such derivative work copyrights is also implicated by the activities of filkers. Because filking typically involves the transformation or modification of previous work, filkers often produce what copyright law calls "derivative works," or "adaptations." The U.S. Copyright Act defines a derivative work as "a work based upon one or more preexisting works, such as a translation, musical arrangement, dramatization, fictionalization, motion picture version, sound recording, art reproduction, abridgment, condensation, or any other form in which a work may be recast, transformed, or adapted." ${ }^{, 61}$ For example, if a filker took preexisting song lyrics, whether still protected by copyright or in the public domain, and recast, transformed, or adapted the lyrics, the filker would have created a derivative work. The filker could claim copyright protection only in the new material she had added, not in any of the material drawn from the preexisting work. ${ }^{62}$ Moreover, the filker's copyright would not extend to any portion of the derivative work in which the preexisting material had been used unlawfully. ${ }^{63}$ Thus, if the filker had made unauthorized use of a copyrighted work, she could claim no protection for portions that had been used in an infringing manner-unless the filker's use was considered a fair use. ${ }^{64}$

Thus, in the absence of protection under the compulsory license provision, the public performance exemptions, or another exception recognized by copyright law, filkers must rely on the doctrine of fair use to justify the lawfulness of their unauthorized creations.

\section{B. Fair Use}

Fair use is often the best candidate for shielding a creative imitator's unauthorized use of copyrighted material, but the doctrine is often difficult to apply in specific cases. Fair use is a judge-made, equitable rule of reason that since 1978 has been codified in U.S. copyright law. ${ }^{65}$ It renders

60. See $\S 115(a)(2)$ (denying a compulsory license where the musical arrangement alters the fundamental character of a work without express consent of the copyright owner).

61. See 17 U.S.C. $\S 101(2006)$.

62. See 17 U.S.C. $\$ 103$ (b) (2006) ("The copyright in a ... derivative work extends only to the material contributed by the author of such work, as distinguished from the preexisting work employed in the work, and does not imply any exclusive right in the preexisting material.").

63. $\S 103(a)$.

64. 17 U.S.C. $\S 107$ (2006).

65. See $\$ 107$ (codifying fair use in the U.S. Copyright Act, originally enacted as Pub. L. 94-553, 90 Stat. 2541, in 1976); 17 U.S.C. $\$ 301(a)(2006)$ (stating that as of January 1,1978 , the title governs all legal or equitable rights regarding the general scope of copyright). 
lawful certain unauthorized and otherwise infringing acts. Section 107 provides that certain types of uses--criticism, commentary, news reporting, research, scholarship, and teaching are mentioned as nonexclusive examples-are not infringing if they satisfy judicial analysis under four nonexclusive factors: (1) the purpose or character of the use, including whether the use is of a commercial nature or is for nonprofit educational purposes; (2) the nature of the copyrighted work; (3) the amount and substantiality of the portion used in relation to the copyrighted work as a whole; and (4) the effect of the use on the potential market for or value of the copyrighted work. ${ }^{66}$ As the breadth of these factors suggests, the fair use doctrine is not a brightline rule, but instead is a flexible, contextspecific standard that must be applied in the particular circumstances to determine whether a given use is lawful or infringing.

Suppose that a filker uses the melody of Barry Manilow's 1974 hit recording Mandy ${ }^{67}$ and creates witty new lyrics to accompany the melody. She calls her version "Randy" and offers it as a critique of male-female relationships. The filker performs "Randy" at various "cons." Whether the use is a fair use will depend on a careful application of each of the four factors. As for the first factor, a court might conclude that the purpose of the filker's use is not exactly commercial-the filker does not collect admission fees or receive other remuneration for her con performances ${ }^{68}$ yet the court might not feel that the use is for typical nonprofit educational purposes either. Perhaps there is no other reason for the filker to use the Manilow tune except that it is recognizable and is likely to elicit a humorous response from middle-aged con attendees.

As for the second factor, the nature of the copyrighted work, a court would typically regard the nature of a song like Mandy as creative and therefore entitled to strong copyright protection. ${ }^{69}$ Under the third factor, the amount and substantiality of the portion used in relation to the copyrighted work as a whole, it can be assumed that the filker has used most or all of Manilow's song rather than a small portion of it, and that this would cut against a finding of fair use. But does the filker's use have any impact on the potential market for or value of Mandy? Likely not, unless the filker posts "Randy" on YouTube or distributes CDs of it to the public, or the filker takes "Randy" on the road as a profitable performance

66. See $\S 107$.

67. See BARRY MANILOW, Mandy, on BARRY MANILow II (Bell Records 1974) (lyrics by Scott English and music by Richard Kerr).

68. Cf. A\&M Records, Inc. v. Napster, Inc., 239 F.3d 1004, 1015 (9th Cir. 2001) (stating that direct economic benefit, such as financial gain or payment, is not necessary for a use to be deemed commercial).

69. See id. at 1016 (noting that creative works are closer to the core of intended copyright protection than are fact-based works). 
vehicle. $^{70}$ Thus, the fourth factor might be extremely important in this case. As a general matter, though, determining fair use may be a close call since the factors do not overwhelmingly favor either the filker or the copyright owner. $^{71}$

A court would probably take a closer look at the first factor: the purpose and character of the allegedly infringing use. ${ }^{72}$ Typically, a court would inquire whether and to what degree the filker's use was "transformative," i.e., not simply a slavish reproduction of the copyrighted work (thus creating a market substitute), but rather a use that "adds something new, with a further purpose or different character, altering the first with new expression, meaning, or message.,"73 One recently litigated case involved a video that a mother had made of her toddler dancing in the kitchen to a Prince recording playing in the background. She posted the video on YouTube, and Prince's lawyers reacted by demanding that YouTube remove the video under the take-down provisions of the Copyright Act. ${ }^{74}$ The court ruled that the lawyers should have considered whether the use was a fair use (that is, whether the addition of the homemade video to the Prince recording was transformative) before resorting to the take-down procedure. Other recent examples of judicially recognized transformativeness in the fair use context have included: reduced images of copyrighted Grateful Dead posters reproduced in a history of The Grateful Dead $; 5$ reproduction of copyrighted material in the form of small thumbnail images used for searching the Internet; ${ }^{76}$ a portion of a copyrighted fashion photograph used in a large montage of pop-culture images critical of the commodification of women; ${ }^{77}$ fifteen seconds of John Lennon's copyrighted song and recording Imagine used to accompany images of the Cold War in a film documentary on attitudes towards religion

70. See id. (stating that if the intended use of the work is for commercial gain, then the likelihood of market harm for the original work can be presumed).

71. Contra id. at 1015-19 (finding that there is likely no fair use defense when all four factors support the copyright owner's allegations).

72. See Campbell v. Acuff-Rose Music, Inc., 510 U.S. 569, 579 (1994) (stating that in looking at the purpose and character of the use, a finding that the work is "transformative" will have more significance in finding a fair use even when the other three factors weigh against such a finding).

73. See id. (noting that even though a transformative purpose is not absolutely necessary to find fair use, transformative works further the goals of copyright).

74. Lenz v. Universal Music Corp., 572 F. Supp. 2d 1150 (N.D. Cal. 2008).

75. Bill Graham Archives v. Dorling Kindersley Ltd., 448 F.3d 605 (2d Cir. 2006).

76. See Kelly v. Arriba Soft Corp., 336 F.3d 811 (9th Cir. 2003) (applying the four factors in finding that the reproduction of the plaintiff's images for use as thumbnails in the defendant's search engine constituted a fair use).

77. See Blanch v. Koons, 467 F.3d 244 (2d Cir. 2006) (finding that the use of a copyrighted photograph in a collage displayed in a museum, where a part of the photograph was altered, constituted a fair use). 
in America; ${ }^{78}$ and a copyrighted segment of a conservative talk-radio rant against "Islamic terrorists" placed by an Islamic group on its website for the purpose of subjecting the talk-show attack to criticism and commentary. ${ }^{79}$

Under these precedents, is the filker's setting of the Manilow tune to different, original lyrics a transformative fair use? Possibly. A court would have to examine the context and particular facts very carefully. But it certainly is more transformative than simply reproducing Manilow's recording Mandy without more, or creating a version that left the original lyrics unchanged. Perhaps "Randy" is like the possible fair use in Lenz, where the Prince recording was used as a background for a toddler's kitchen dance.

Fair use does not always work as a defense in the context of music. It is not settled, for example, whether rappers' use of sampled sound recordings in their own recorded performances is a fair use. ${ }^{80}$ Some courts have laid down something approaching a brightline rule prohibiting unauthorized sampling. ${ }^{81}$ If a fair use defense was raised in a sampling case, the result might well depend on whether the court viewed the sampled portion as having been transformed within the context of the rap recording, or whether the court considered the sample as having simply been lifted and used, untransformed, within the second recorded performance. ${ }^{82}$ Because filkers rarely, if ever, sample actual recordings, however, fair use in the sampling context will likely remain of limited interest to filk culture.

\section{Parody as Fair Use}

Filkers are much more likely to find fair use parody relevant to their activities. An interesting example is the case of Abilene Music, Inc. v. Sony

78. See Lennon v. Premise Media, 556 F. Supp. 2d 310 (S.D.N.Y. 2008) (stating that the four factors demonstrate that the defendants likely have a fair use defense in their use of the recording).

79. See Savage v. American-Islamic Relations, Inc., 2008 WL 2951281 (N.D. Cal. 2008) (finding that the use of the audio constituted a fair use because the use served a different function from the original and was therefore transformative).

80. Compare Newton v. Diamond, 338 F.3d 1189, 1192 (9th Cir. 2004) (finding that a hip-hop group's sampling of a sequence in its own song was de minimis and not infringing), with Bridgeport Music, Inc. v. Dimension Films, 383 F.3d 390, 393 (6th Cir. 2004) (holding that a rap song that sampled a copyrighted song was infringing).

81. See, e.g., Bridgeport Music, 383 F.3d at 398-99 ("Get a license or do not sample."); see also Anthony Falzone, Diddy Could Save Sampling: Why Hasn't He or Any Other Big-Name Rapper Even Tried? SLATE, Nov. 2, 2007 , http://www.slate.com/id/2177238 (demonstrating how many defendants in cases involving sampling in rap songs fail to raise fair use as an explicit defense).

82. See Campbell v. Acuff-Rose Music, Inc., 510 U.S. 569, 579 (1994) (stating that courts look to whether a work is transformative in determining whether a use constitutes fair use). 
Music Entertainment, Inc. ${ }^{83}$ This was not a sampling case, but rather one in which rapper Ghostface Killah took some of the lyrics of What a Wonderful World (made famous by the Louis Armstrong version), transformed them, and used them as a basis for a lurid exposition of drugs and sexual exploitation in the urban environment. ${ }^{84}$ The Court held this use to be a "parody," and therefore a fair use, because it "criticiz[ed] and ridicul[ed] the cheerful perspective" of the original song, offering commentary on "lost innocence" and "the naiveté of mainstream culture." 85

Parody was famously deemed to be an important type of transformative fair use in Campbell v. Acuff-Rose Music, Inc., in which the U.S. Supreme Court held that the rap group 2 Live Crew's bawdy version of Roy Orbison's Oh, Pretty Woman might qualify as a fair use parody ${ }^{86}$ Parody is a fair use when it is employed to critique or comment upon the copyrighted work directly. For example, 2 Live Crew's rap riff on $O h$, Pretty Woman specifically targeted for ridicule Orbison's sentimentalized song about encountering an attractive woman in the street.

But not all such imitations are parody. Some courts have concluded that when the use of the copyrighted work is only a "satire" (as opposed to parody)-i.e., when the copyrighted work is used merely as a springboard for attacking something unrelated to the copyrighted work-then the use is infringing. ${ }^{87}$ An example of satire can be found in Dr. Seuss Enterprises, L.P. v. Penguin Books USA, Inc., in which the owner of the Dr. Seuss copyrights sued a publisher that had issued a book lampooning the O.J. Simpson criminal trial by borrowing the distinctive rhymes, style, and cartoon imagery of The Cat in the Hat. ${ }^{88}$ The court held that the book was not parody since it did not directly critique the Dr. Seuss work, but, instead, merely exploited The Cat in the Hat as a way of satirizing the Simpson trial. ${ }^{89}$ Hence, the use was infringing, not a fair use.

Now suppose that, in our Mandy hypothetical, the filker uses the song in

83. See Abilene Music, Inc. v. Sony Music Entm't, Inc., 320 F. Supp. 2d 84, 94 (S.D.N.Y. 2003) (holding that Ghostface Killah's song constituted a parody and therefore did not constitute copyright infringement).

84. See id. at 87 (describing how the tune of "Wonderful World" was recognizable in "The Forest" but that the latter included slang references to marijuana).

85. See id. at 90 (finding that "The Forest" is a clear parody of "Wonderful World" because "The Forest" provides an ironic contrast to the world portrayed in the original).

86. See 510 U.S. 569, 594 (1994) (holding that the lower court erred in finding that the commercial nature of 2 Live Crew's parody made it presumptively unfair and that 2 Live Crew had necessarily copied excessively from the original song).

87. See generally Dr. Seuss Enter. L.P. v. Penguin Books USA, Inc., 109 F.3d 1394 (9th Cir. 1997) (finding that the defendant's work constituted a satire, not a parody, and therefore was not a fair use of the original copyrighted work).

88. See id.

89. Id. at $1400-01$. 
a way that reproduces some of the original lyrics but does so in order to critique the 1974 hit as indulging sentimental assumptions about men's emotional helplessness and women's supposed duty to provide selfless solace and understanding ("Oh, Mandy, you came and you gave without taking"). ${ }^{90}$ Here, the filker's version, like 2 Live Crew's send-up of $O h$, Pretty Woman and Ghostface Killah's puncturing of What a Wonderful World, would seem to be targeting Mandy for critique or commentary, even though "Randy" might also, incidentally, satirize male-female relations in the culture at large. 91 On these facts, "Randy" would appear to be a transformative parody, adding new, independent expression to the original song which make it less likely to interfere with the actual or potential market for Manilow's recording.

\section{Creative Commons}

Creative Commons is both a nonprofit organization founded by Lawrence Lessig and a cultural movement that seeks to create an alternative to what has been perceived to be an increasingly restrictive, corporate-driven permissions culture. ${ }^{92}$ In place of the usual assumption of copyright owners that permission for any use of a protected work may be obtained only through a negotiated license, Creative Commons erects the assumption that a work may be used according to recognized privileges and exceptions in copyright law, subject to certain requirements of the copyright owner. Creative Commons has promoted the use of certain types of copyright licenses that embody this user-friendly assumption:

Creative Commons licenses give you [the copyright owner] the ability to dictate how others may exercise your copyright rights-such as the right of others to copy your work, make derivative works or adaptations of your work, to distribute your work and/or make money from your work. They do not give you the ability to restrict anything that is otherwise permitted by exceptions or limitations to copyright-including, importantly, fair use or fair dealing - nor do they give you the ability to control anything that is not protected by copyright law, such as facts and ideas. $^{93}$

90. Barry Manilow, Mandy Lyrics, http://www.lyrics.com/lyrics/barrymanilow /mandy.html (last visited Oct. 2, 2009).

91. See Campbell, 510 U.S. at 583 (finding a fair use in 2 Live Crew's song because it could reasonably be perceived as commenting on or criticizing the original); Abilene Music, Inc. v. Sony Music Entm't, Inc., 320 F. Supp. 2d 84, 89 (S.D.N.Y. 2003) (stating that a work is more deserving of fair use protection when it comments on or criticizes the original work and transforms it).

92. See Creative Commons, About Creative Commons, http://wiki.creative commons.org/Frequently_Asked_Questions (last visited Oct. 2, 2009)

93. See id.; see also Creative Commons, Legal Code, http://creative commons.org/licenses/by-nc-nd/3.0/legalcode (providing a broad overview of the legal implications of using the licensing services of Creative Commons that are usable 
Creative Commons licenses might work well within filk culture as a way of formalizing the types of borrowing in which filkers already engage. Indeed, it is probably the case that the type of flexible, creativity-enhancing transactions that Creative Commons hopes to promote through its license forms are already being practiced by filkers, without any need for written licenses. ${ }^{94}$ But filkers borrow from traditional copyright owners at least as often as they borrow from each other. Because dominant copyright culture has not adopted Creative Commons licenses or the attitudes of filkers, Creative Commons licenses are probably of limited utility in filk culture as presently constituted.

\section{SURVEY}

Scholars have begun examining discrete communities with unique intellectual property issues and community-based norms, ${ }^{95}$ and filk is a natural subject for such examination. ${ }^{96}$ As is clear from preceding discussion, filk is not easily classified within the intellectual property laws in the United States. Some filk songs, those that use original lyrics and an original melody, not only do not infringe any existing copyright; they are themselves entitled to copyright protection. And some filk songs, which use copyrighted melodies and universes, are likely infringing, unless they constitute a fair use by virtue of their parodic character or their creative transformativeness.

Despite its being ripe for study, however, the filk community and filk songs have received very little attention from the legal academy. ${ }^{97}$ This article, then, is the first such systematic effort, and it undertakes to explore the intellectual property issues implicated by filk from both a descriptive

worldwide, but still subject to specific laws of the jurisdiction in which the license is obtained).

94. See, e.g., Lunderville, supra note 9; Mel's Filk, http://meltatum.wordpress.com (last visited Oct. 2, 2009) (demonstrating that although many filkers make their lyrics publicly available, several have begun explicitly using Creative Commons licensing as part of their websites).

95. See, e.g., Dotan Oliar \& Christopher J. Sprigman, There's No Free Laugh (Anymore): The Emergence of Intellectual Property Norms and the Transformation of Stand-Up Comedy, 94 VA. L. REV. 1787 (2008); Kal Raustiala \& Christopher J. Sprigman, The Piracy Paradox: Innovation and Intellectual Property in Fashion Design, 92 VA. L. REV. 1687 (2006).

96. Cf. Melissa L. Tatum, Identity and Authenticity in the Filk Community, 3 Transformative Works and Cultures paragraph 2.4 (2009), http://dx.doi.org $/ 10.3983 /$ twc. 2009.0139 .

97. Using the word "filk" as a search term in Westlaw's JLR (journals and law reviews) database reveals only two articles even referencing filk songs. See generally Aaron Schwabach, The Harry Potter Lexicon and the World of Fandom: Fan Fiction, Outsider Works, and Copyright, 70 U. PITT. L. REV. 387 (2009); Aaron Schwabach, Harry Potter and the Unforgivable Curses: Norm-Formation, Inconsistency, and the Rule of Law in the Wizarding World, 11 ROGER WILLIAMS U. L. REV. 309 (2009). 
and an empirical perspective. Since filk spans the entire gamut from original creations to lawful or unlawful derivative works, we focused our study primarily on whether any gender-based differences exist among filkers with respect to copyright. More specifically, we were interested in filkers' attitudes towards intellectual property, as well as the types of songs written by members of different genders. Because several prominent members of the filk community are transgendered, we constructed both our databases using three genders: male, female and transgender. Once the data were gathered, it was immediately clear that the data associated with transgendered filkers were so small as to be statistically insignificant. We thus proceeded with the statistical analysis using only male and female genders. Based on our knowledge of the filk community, and anecdotal information about attitudes toward copyright in the filk community, we hypothesized that we would find no differences between genders, and were quite surprised at the results of our empirical research.

\section{A. Study Methodology}

We built two databases-one consisting of songs themselves and one consisting of answers to a survey. We then analyzed those databases for relationships between gender and the other elements of the database. ${ }^{98}$ The first of our two databases, which contained 895 songs when completed, identified the author's gender and whether the lyrics and/or the melody for each song used copyrighted material. This database provided a source of objective material to use in evaluating connections with gender. To ensure the database contained a random sampling of songs, we pulled songs from three different sources. First, we included songs nominated for a Pegasus Award, the major filk award, which has been in existence for twenty years. ${ }^{99}$ Second, we included songs specifically mentioned in the Filk Hall of Fame induction citations. ${ }^{100}$ We included these two sources on the theory that they represent the best filk songs, or at least the songs the filk community considers to be the best. ${ }^{101}$ To ensure a wide variety of songs, we also included a random sampling of songs published in Xenofilkia, a filk magazine published continuously for the past two decades. ${ }^{102}$ Since all three of these sources span approximately the same twenty-year period, we

98. See app. B.

99. See Ohio Valley Filk Festival, supra note 12.

100. The induction citations are included on the Filk Hall of Fame website, http://www.filkontario.ca/hof/inductees/byname.html (last visited Nov. 14, 2009). 12.

101. See FilkONtario, supra note 13; see also Ohio Valley Filk Festival, supra note

102. See Xenofilkia, Cumulative Xenofilkia Index by Author, http://the starport.com/xeno/ix.auth.html (last visited October 17, 2009) (listing all of the songs published in the magazine since its inception). 
also broke the database into five year increments: 1988-1992; 1993-1997; 1997-2002; 2003-2007; and 2008-present, so we could explore both connections with gender and whether those connections varied over time. ${ }^{103}$

The second database consists of the responses to a survey questionnaire administered to members of the filk community. ${ }^{104}$ The survey was admittedly not administered in a scientifically calculated method. We distributed the survey over a three-month period via various filk community listservs, at a major filk convention, and via the filk community's LiveJournal website. ${ }^{105}$ We received sixty-two responses, which we are guessing constitutes somewhere between $5 \%$ and $10 \%$ of the active filk community. ${ }^{106}$ The survey solicited four types of information: basic background information about the responder; whether the responder had written, performed, and/or recorded different types of filk songs; narrative information about each responder's understanding of copyright and intellectual property law; and narrative information about each responder's attitudes and approaches to copyright and intellectual property law. The information in this second database is more subjective and provides anecdotal (as opposed to scientific) data for exploring current connections between gender and attitudes toward intellectual property. ${ }^{107}$

\section{B. Findings}

Given that most filk exists in the shadows of intellectual property laws, skirting the edges of copyright or plunging unawares into the heart of fair use, we went into this project expecting to find little difference between the genders with respect to attitudes toward intellectual property. We had no idea, however, what to expect in terms of the types of songs written by members of the different genders. In this section, we discuss some of our more significant statistical findings. For those interested in the complete details, we have included the statistical tables and results for all our findings as appendices. ${ }^{108}$ The statistical results from the song database are

103. For the random sampling of songs published in Xenofilkia, we decided to randomly select seven issues from each of the time periods. We placed the issue numbers for each time frame in a column, used Excel's randomize sort function, and used the first seven on randomly sorted list for each category. We ended up with issues: $2,3,5,14,16,26,27 ; 30,32,34,41,43,48,56 ; 58,59,60,69,72,79,82 ; 92$, $93,98,100,107,112,113 ; 117,118,119,120,121,122$, and 123 .

104. See infra app. D.

105. See Live Journal, http://community.livejournal.com/filk (last visited Oct. 3, 2009).

106. No data exist regarding the actual size of the filk community; this guess is based on the personal experiences of Melissa Tatum, who is herself a member of that community.

107. See infra app. B (noting that the database only contains two songs by transgender authors).

108. See infra apps. B and D (providing the results of the survey in the song 
in Appendix B; the survey instrument used for the survey database is set out in Appendix C; and the statistical results from the survey database are contained in Appendix D. ${ }^{109}$

\section{Song Database}

For the song database, we evaluated whether there were genderassociated differences in many filk characteristics, such as the presence of a co-author, the originality of the lyrics, the originality of the melody, whether the author had been published in Xenofilkia, and whether the author had been nominated for a Pegasus award. Among these characteristics, three showed strong evidence of dependence on gender, that is, had a p-value less than 0.05 ; one showed weak evidence of dependence on gender, that is, had a p-value between 0.05 and 0.10 ; and two showed no evidence of a dependence on gender, that is, had a p-value greater than 0.10 .

As mentioned earlier, the final song database contained 895 entries. Of those songs,

- 536 had a male author

- 286 had a female author

- 15 were written by female co-authors

- 22 were written by male co-authors; and

- 32 were written by male and female co-authors. ${ }^{110}$

Although we had not originally intended to divide the song database into time periods, our last minute decision to do so generated some highly interesting results and provided one of the three areas showing strong dependence on gender. The rates of publication appear highly connected with gender. ${ }^{111}$ As figure one shows, although men and women initially published songs at roughly the same rate twenty years ago, men quickly began outpacing women in the rate of publication, and indeed, between the late 1990's and early 2000's, there was a sharp decline in the number of songs published by women. ${ }^{12}$

databases).

109. See infra apps. B and D (reporting the survey instruments and results).

110. For those doing the math, that adds up to 891 songs. Of the four remaining songs, two were by transgendered authors and two were by female authors with an unknown co-author. We did include all 895 songs in our statistical computations. See infra app. B.

111. See figure 1 (demonstrating the gender differences in publication were once minimal and that they became more noticeable after 1992).

112. Id. 


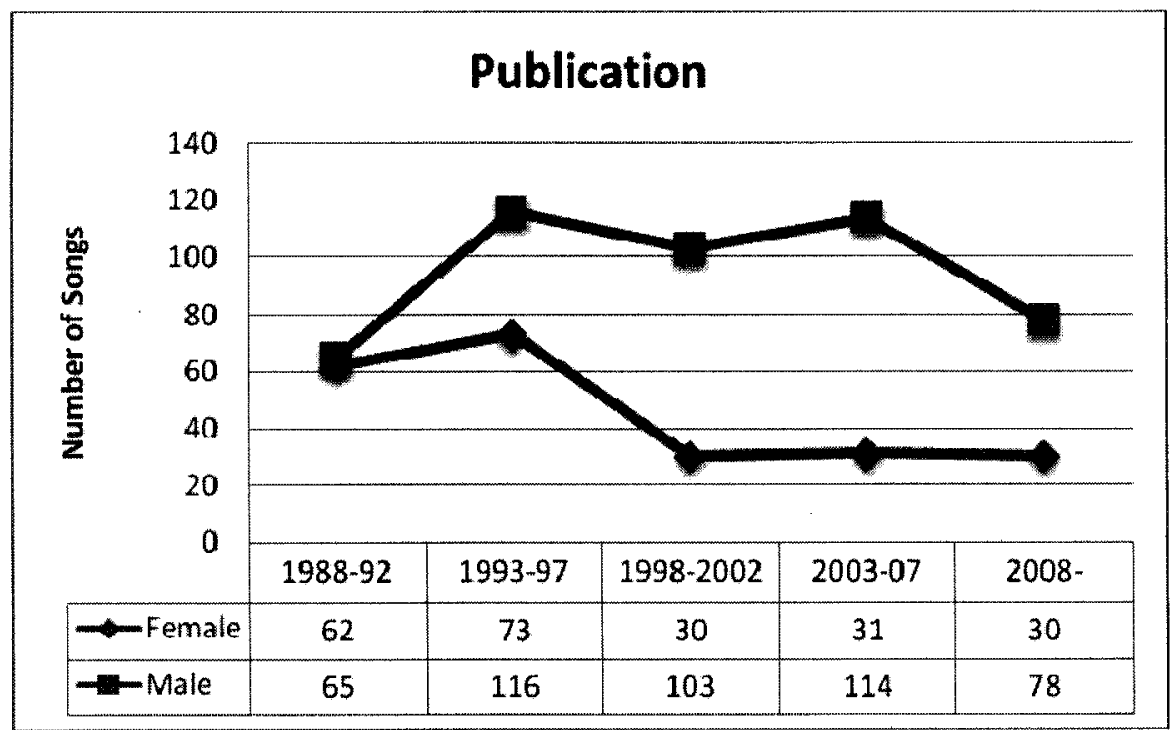

Figure 1

Despite the fact that men publish songs at a greater rate than women, there was strong evidence that females are more likely to be nominated for a Pegasus Award. ${ }^{13}$ For example, $6.1 \%$ of females received multiple nominations, as compared with $3.4 \%$ of males; and $84.3 \%$ of males have never been nominated for a Pegasus, as compared with $74.4 \%$ for females. $^{114}$

It is interesting to speculate about the disparity in nominations (particularly in light of the rates of publication). With the exception of the 2003-2007 time span, men and women were nominated for Pegasus Awards in very similar raw numbers. ${ }^{15}$ The raw numbers for multiple nominations are also very similar-nineteen females and twenty males were nominated multiple times.

113. Cf. Ohio Valley Filk Festival, Pegasus Awards, http://ovff.org/pegasus (last visited Sept. 17, 2009) (showing the nomination procedures and sources).

114. Id.

115. It is not entirely clear why the 2003-2007 time period is so very different from previous time periods. We have shared our results with the filk community both online and at conventions, and two common explanations have been proffered. The first has to do with the rise of various technologies for distributing songs (such as the internet and $\mathrm{mp} 3 \mathrm{~s}$ ), which may provide an advantage to those who are likely to be at the cutting edge of such technologies (usually males), as they may more easily expand their audience. The second is a change in nomination procedures for the Pegasus awards. We think it likely that both explanations are relevant. See figure 2. 


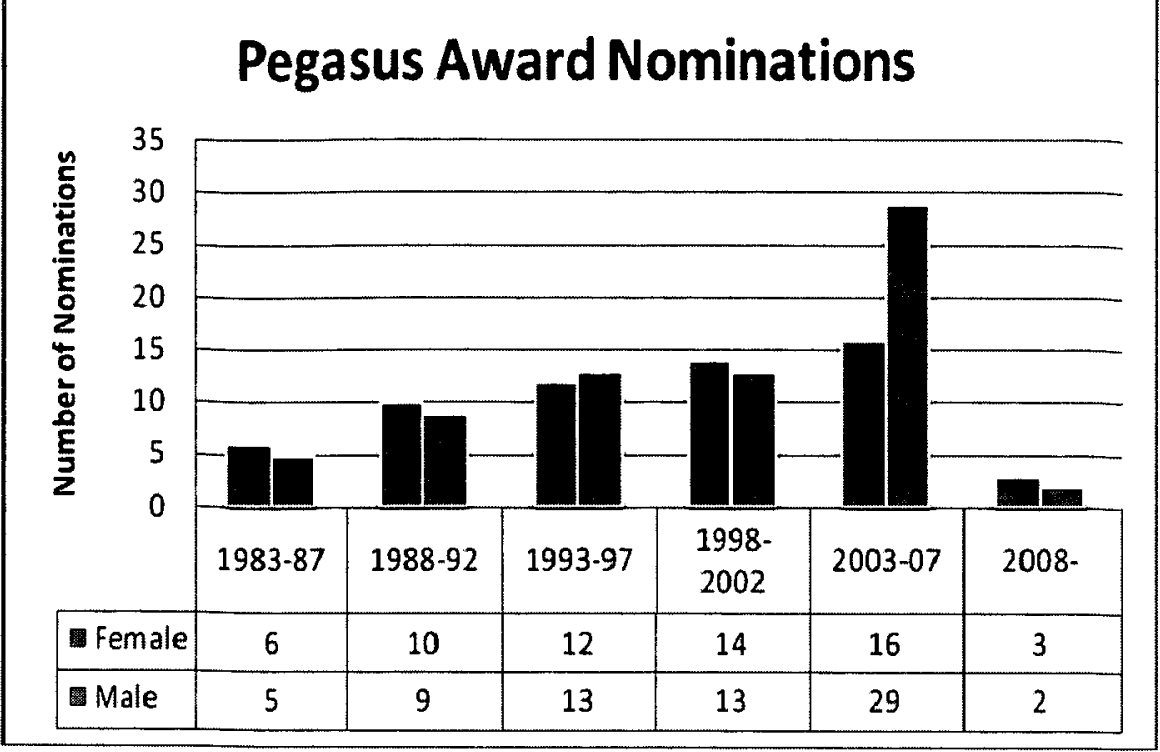

Figure 2

This could simply reflect either a conscious or subconscious effort to distribute nominations equally among men and women. We cannot help but speculate, however, whether the disparity in nominations is at least to some degree influenced by the originality of the lyrics and the melody. The statistics show that the type of melody is strongly dependent on gender. ${ }^{116}$ For example, females were more likely to use completely original melodies (females $30.0 \%$, males $21.4 \%$ ), while males were more likely to use a copyrighted melody (males $40.5 \%$, females $35.1 \%$ ) or the melody of another filker (males $25.2 \%$, females $19.5 \%$ ). ${ }^{117}$ Put differently, $45.3 \%$ of females used a melody that was not subject to someone else's copyright, while only $34.3 \%$ of males did. Conversely, $65.7 \%$ of males borrowed someone else's copyrighted melody, while only $54.6 \%$ of females did. ${ }^{118}$

This last statistic may also explain part of the disparity in publication rates. We chose Xenofilkia as the primary source of our song database because it has been in continuous publication for over twenty years with a consistent editor. ${ }^{119}$ The nature of its format, however, means that it tends

116. See infra figure 10 (reporting the participants' self-reported melody usage).

117. See infra figure 3 (reporting data on melody source).

118. Id.

119. See generally Xenofilkia Home Page, http://www.conchord.org/xeno/ (last visited Oct. 17, 2009). 
to lean heavily towards songs that are "to the tune of" another melody; it is not set up to publish many songs with original melodies. Other songbooks, such as the GAFilk Songbook, have a format suited to and a preference for original melodies, so future studies should be more inclusive with respect to magazine format.

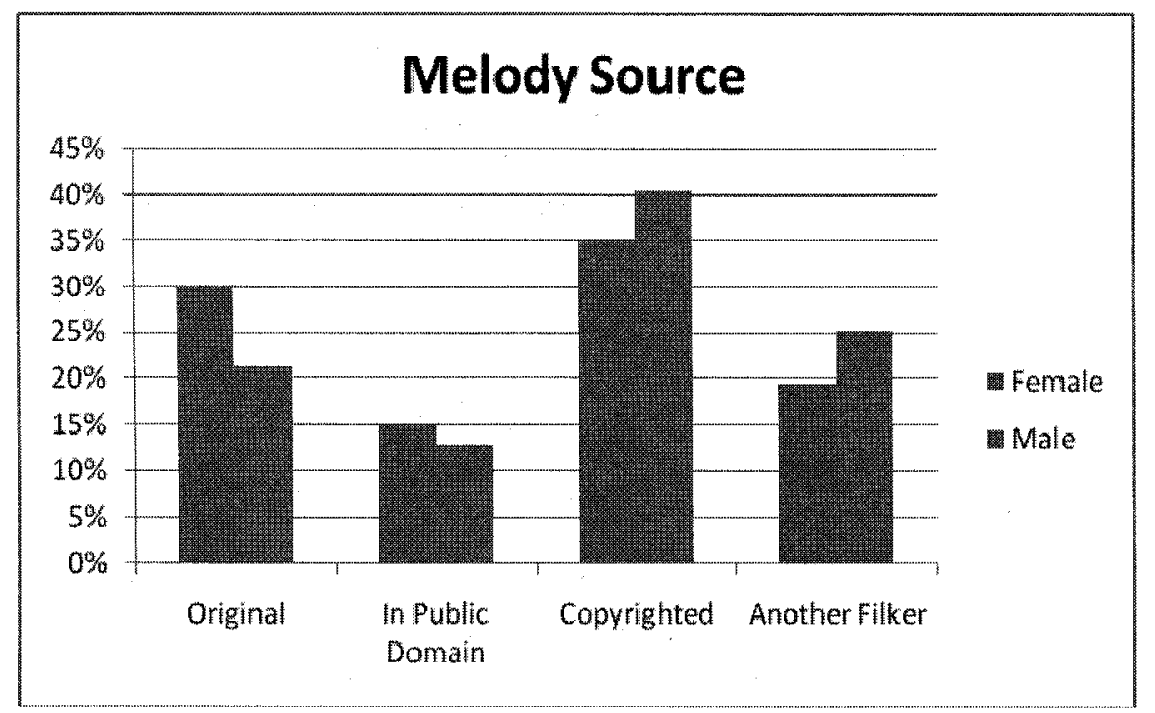

Figure 3

There is weak evidence that the originality of the lyrics used is dependent on gender, although the originality runs the opposite direction here from the originality with respect to the melody. With respect to lyrics, males were slightly more likely to use completely original lyrics $(62.2 \%$ males, $54.6 \%$ females), while females were slightly more likely to use lyrics based on another's characters or universe (females $45.4 \%$, males $37.8 \%)^{120}$

120. See infra figure 4 . 


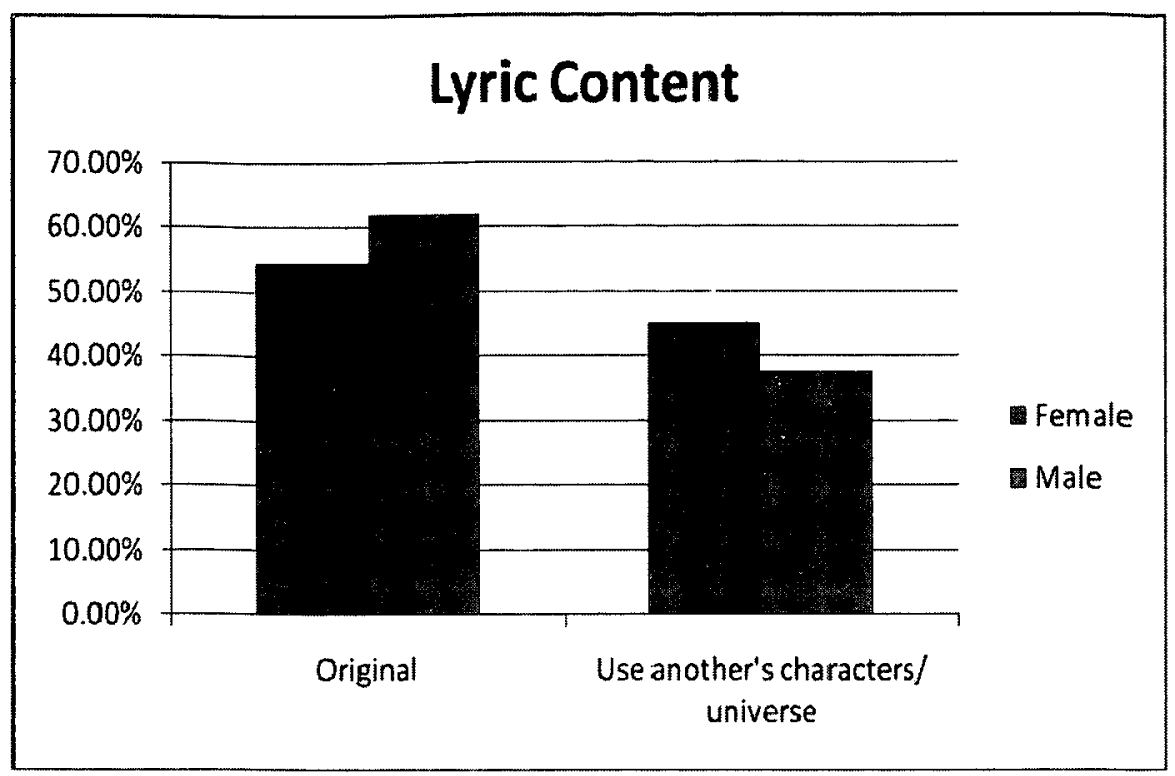

Figure 4

\section{Filk Survey Database}

For the filk survey database, we elicited four general categories of information from each responder: basic background information; the types of filk songs written, performed and/or recorded by the responder; the responder's understanding of copyright and intellectual property ("IP") law; and the responder's opinions about that law. ${ }^{121}$ For each type of information, we evaluated whether there were gender-dependent differences among the respondents.

\section{E. Basic Background}

Of the sixty-two responses we received, thirty-three $(53 \%)$ were from females and twenty-nine $(47 \%)$ were from males. ${ }^{122}$ We inquired about age, length of time involved in filk, educational background, occupation, and nationality. ${ }^{123}$ With the exception of occupation, none of these variables was dependent on gender. Occupation, however, showed strong evidence of dependence on gender. Females were more likely to be artists (females $9.1 \%$, males $3.4 \%$ ), work in clerical jobs (females $6.1 \%$, males

121. See infra app. C.

122. See id.

123. See infra figures 5-9 (setting forth the information collected from survey participants). 
$0 \%$ ), be musicians (females $6.1 \%$, males $0 \%$ ), work in sales/marketing (females $6.1 \%$, males $0 \%$ ), or be teachers (females $12.1 \%$, males $6.9 \%$ ); while males were more likely to work in technical jobs (males $62.1 \%$, females $15.2 \%$ ) or be students (males $6.9 \%$, females $3.0 \%$ ). ${ }^{124}$

Approximately one-third of the survey respondents had been involved in the filk community for more than twenty years, and approximately one-half of the survey respondents had been involved in filk for more than fifteen years. ${ }^{125}$ The educational level of the respondents was also quite high, with over $40 \%$ having a college degree and approximately $40 \%$ holding a graduate degree. ${ }^{126}$ The number of male and female respondents holding college degrees was roughly equal, as was the number of males and females holding graduate degrees. ${ }^{127}$

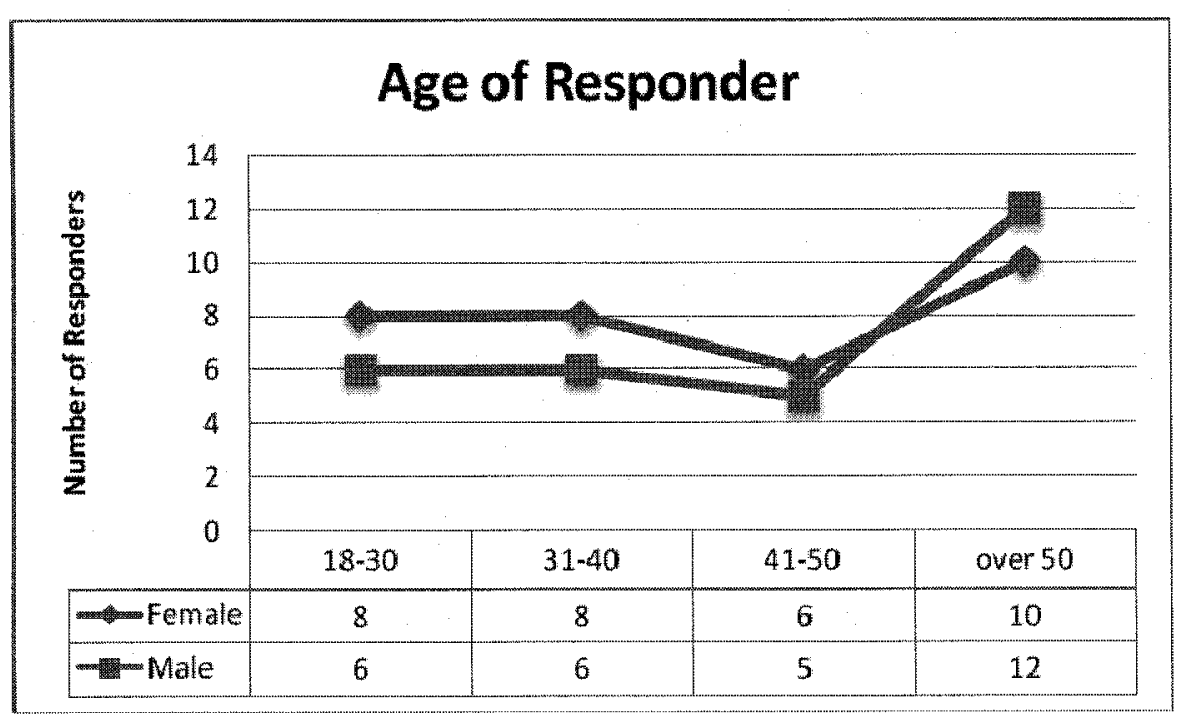

Figure 5

124. See figure 9 infra.

125. Id.

126. Id.

127. Id. 


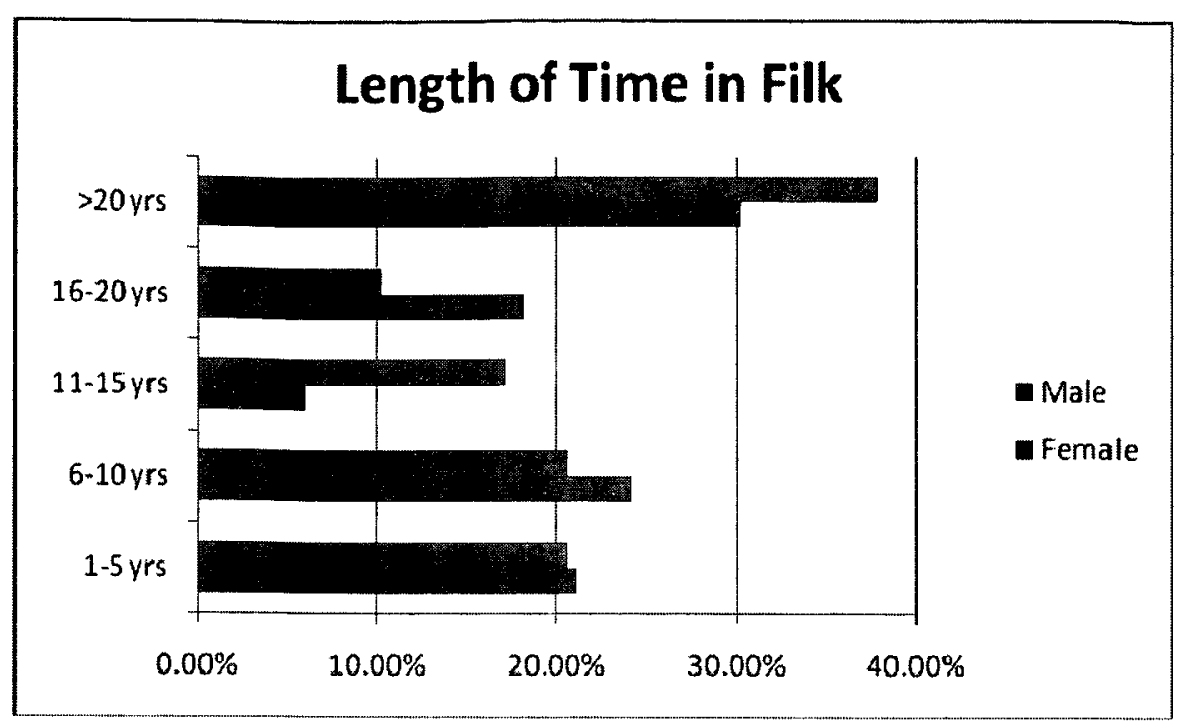

Figure 6

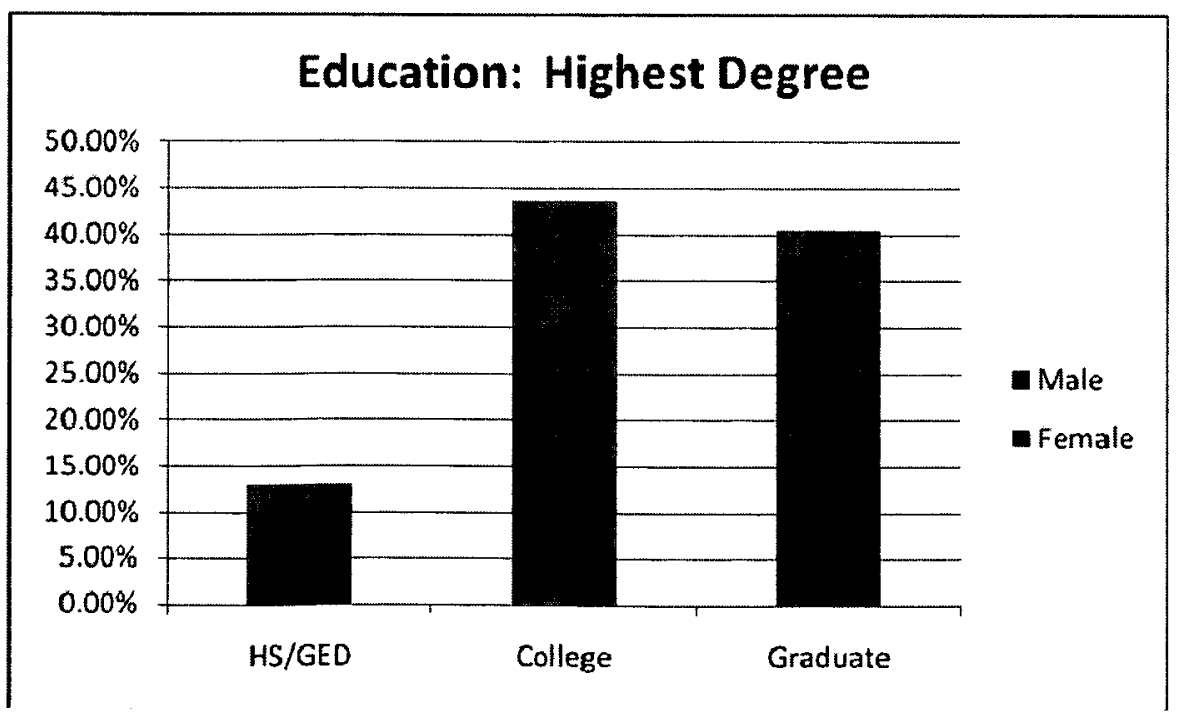

Figure 7 


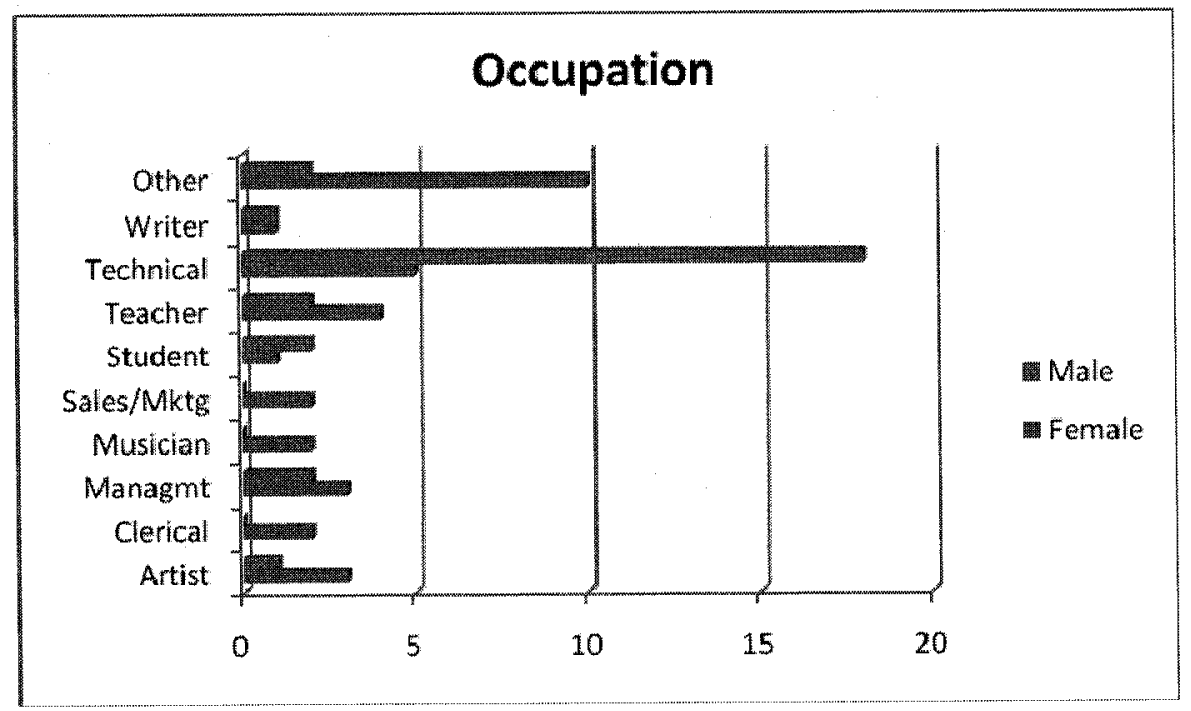

Figure 8

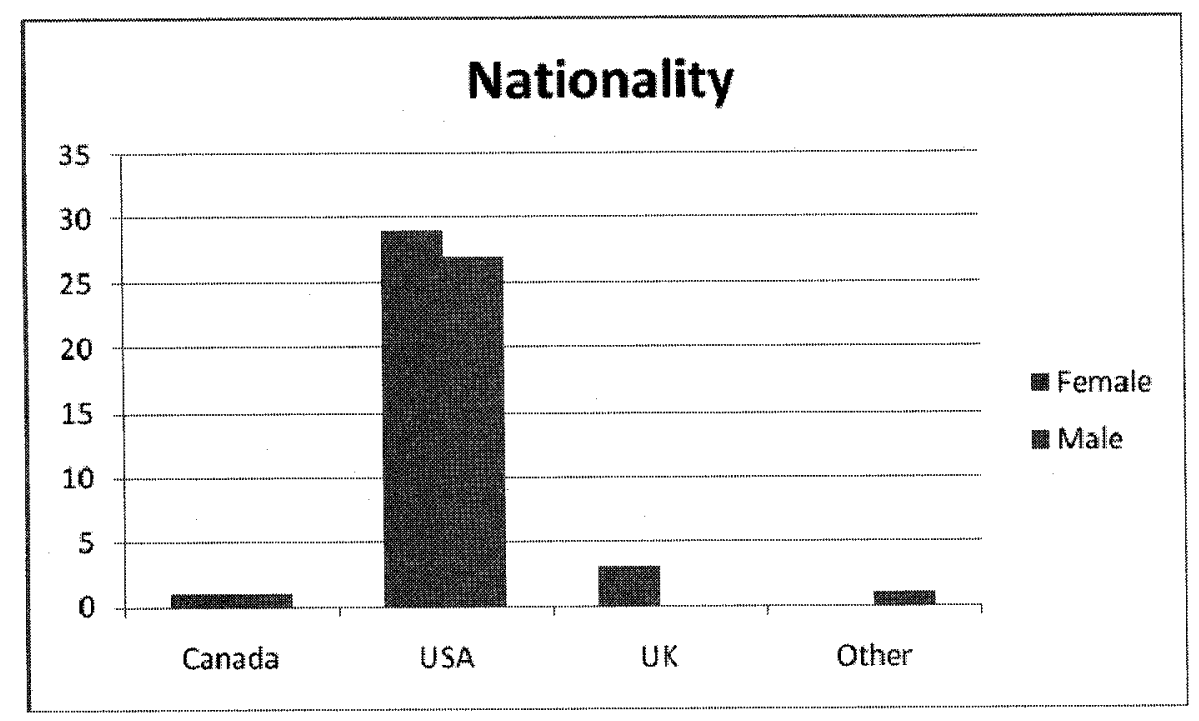

Figure 9 


\section{F. Types of Songs}

The survey instrument contained a list of eight statements relating to types of songs written, performed, and/or recorded and asked responders to check all that applied:

- I have written new lyrics for existing melodies;

- I have written lyrics based on characters/worlds created by another person;

- I have written songs with original lyrics and original melodies;

- I have performed songs written by another person;

- I have recorded songs written by other people;

- I have recorded songs containing lyrics I wrote set to an existing melody;

- I have recorded songs containing lyrics I wrote based on characters/worlds created by another person; and

- I have recorded songs with original lyrics and original melodies.

We analyzed whether any gender-dependence existed for each item on the list. One showed weak evidence of dependence-males are more likely to perform songs written by another person (males $89.7 \%$, females $81.8 \%$ ), but otherwise found no gender-related differences. ${ }^{128}$

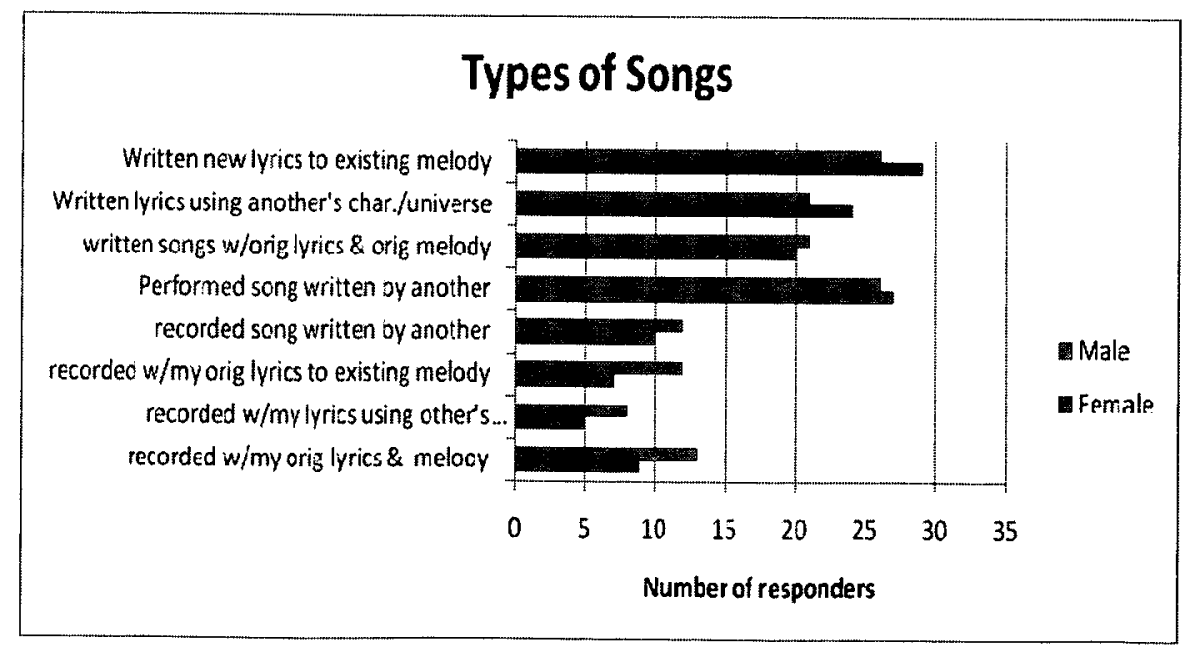

Figure 10

\section{G. Understanding of Copyright and Intellectual Property Law}

The survey elicited narrative answers to several questions seeking information about the responders' understanding of copyright and IP law. We reviewed the answers and coded them into a number of categories:

128. See figure 10. 
- whether the user should credit the original author;

- whether one should ask before using another's work;

- whether someone tries to use only tunes in the public domain;

- whether there is no problem using someone else's intellectual property as long as the user does not earn money;

- whether there is not a problem if the user does not perform the work publicly;

- whether the user only performs the "adopted" works in informal song circles;

- whether copyrighted works are recorded without permission;

- whether all legal requirements are considered; and

- whether the user thinks about the laws they are violating.

We analyzed whether there were gender-related differences for each category. ${ }^{129}$

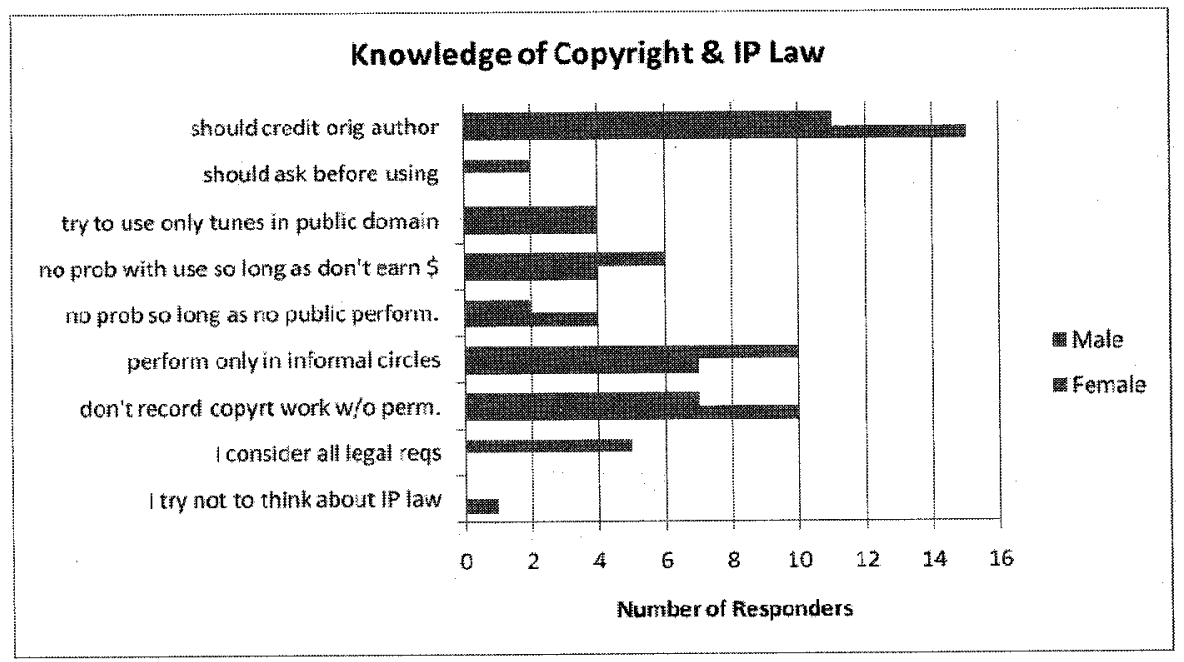

Figure 11

Among these categories, the only category that showed a strong evidence of gender-bias was whether all legal requirements were considered (males $17 \%$, females $0 \%$ ). ${ }^{130}$ The only other category that showed even weak evidence of dependence on gender was whether the songs were performed exclusively in informal song circles (males 34.5\%, females $21.2 \%$ ). ${ }^{131}$

We also explicitly asked how each responder defined "fair use." "We

129. See figure 11.

130. Id.

131. Id.

132. See figure 12 . 
coded the answers according to several categories and analyzed whether there were gender-linked differences for each category:

- not profiting from other people's work;

- includes an obligation to credit the original author in the definition;

- parody is okay and not a violation;

- is only acceptable to use a small snippet of the original;

- is acceptable to use works for education purposes;

- is acceptable to use others' works for private entertainment or for a group of friends;

- must get permission and/or pay royalties before performing the work, and

- those who leave fair use "to the lawyers."

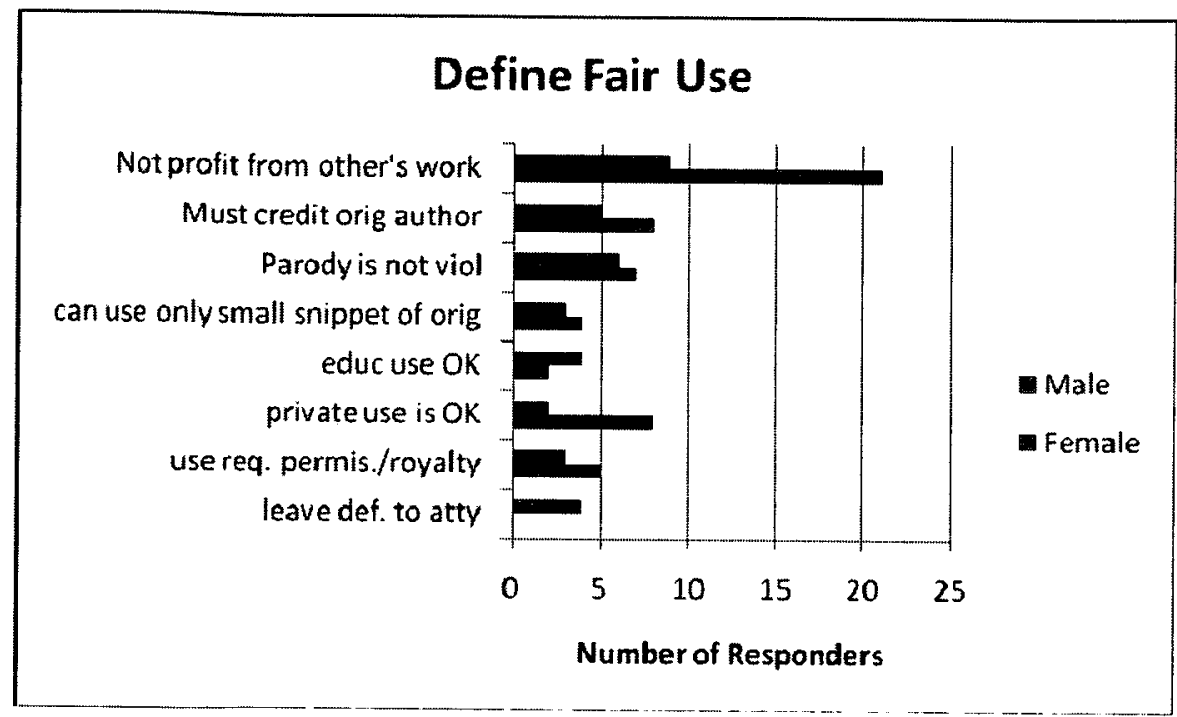

Figure 12

The researchers analyzed whether there were gender-linked differences for each category. ${ }^{133}$ Among these categories, only one showed strong evidence of dependence on gender, and only one showed weak evidence of dependence. Whether fair use includes not profiting from others' work showed strong evidence of dependence on gender (females $63.6 \%$, males $31.0 \%$ ), while the proportion of people who leave fair use definitions "to the lawyers" showed weak evidence of dependence on gender (males $13.8 \%$, females $0 \%$ ). ${ }^{134}$

133. Id.

134. Id. 
H. Attitudes and Approaches to Copyright and Intellectual Property Law

The survey solicited a narrative answer to the question "What is your opinion of current copyright laws?" and also inquired whether the responder had ever registered a copyright for any work, whether the responder had ever registered a copyright for a filk-related work, and whether the responder participates in Creative Commons. ${ }^{135}$ We coded the narrative answers into several categories and analyzed whether there were gender-associated differences for each:

- copyright is outdated;

- copyright is irrelevant in light of technology;

- copyright lasts too long;

- penalties are too severe;

- copyright works fine;

- copyright gives too much control to corporations as opposed to the individual creator;

- copyright is too limiting and allowing some degree of use promotes market for the original;

- copyright law is too ambiguous and confusing;

- copyright law suppresses creativity;

- enforcement costs too much; and

- don't know enough about copyright law to form an opinion.

Among these categories, only one showed strong evidence of dependence ( $\mathrm{p}$-value $<.05$ ), and two showed weak evidence of dependence $(.05<\mathrm{p}$-value $<.10){ }^{136}$ The belief that copyright lasts too long showed strong evidence of dependence on gender (males $51.7 \%$, females $24.2 \%$, $\mathrm{p}=.04865$ ), while the proportion of people who did not know enough about copyright law to form an opinion showed weak evidence of dependence on gender (females $21.2 \%$, males $3.4 \%, \mathrm{p}=.08872$ ). ${ }^{137}$ There is also weak evidence that males are more likely to have participated in Creative Commons (males $44.8 \%$, females $18.2 \%$, $\mathrm{p}=.05711$ ). ${ }^{138}$

135. See infra app. C.

136. Id.

137. $I d$.

138. Id. 


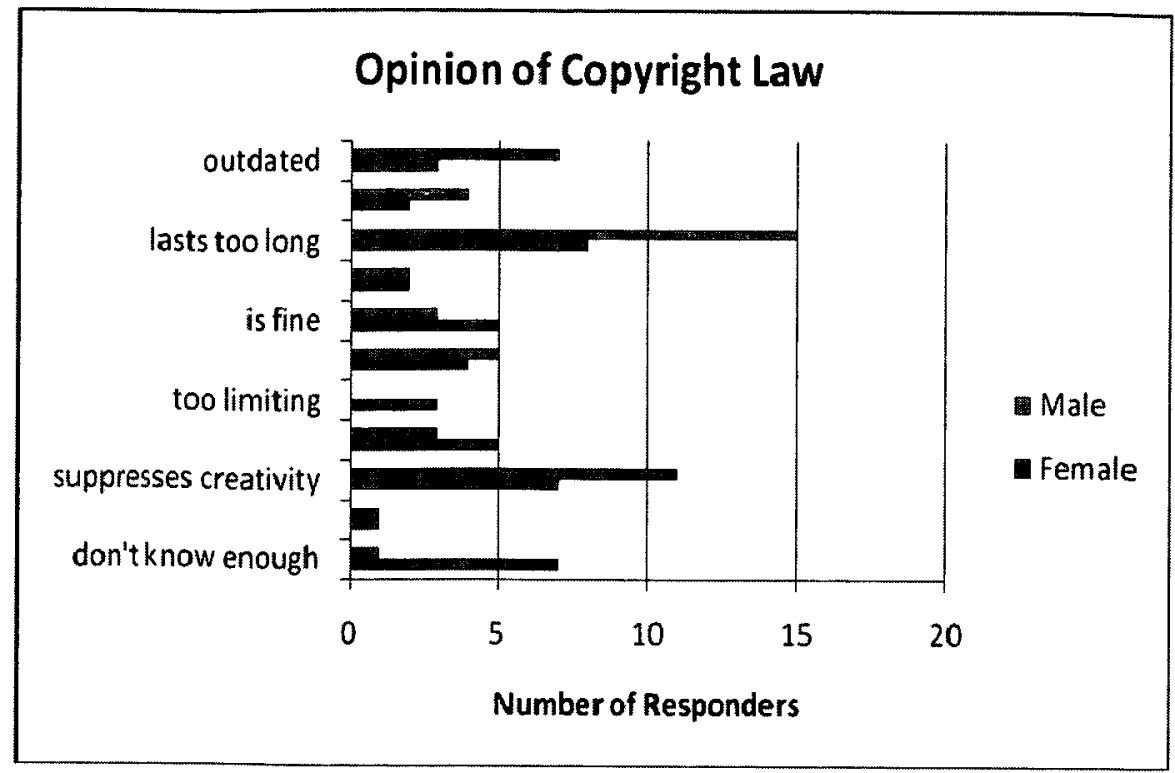

Figure 13

\section{Conclusion}

Because this is the first attempt at any systematic study of intellectual property and the filk community, we chose to undertake a small, initial survey to determine whether broader, more comprehensive studies are warranted. Almost by definition, the first foray into a new field must be a "scouting report" rather than a full-fledged topographical survey. Thus, our sampling of filk responses is too limited to derive any strong conclusions from the data. Rather, the purpose of our study is to provide a foundation for further study and examination.

While we caution against drawing strong conclusions from the data, certain tentative inferences are suggested by those data. Women in the filk community are more likely than men to create original melodies to accompany their lyrics (Figure 3), while women are only somewhat more likely to borrow from others' lyrics than are men (Figure 4). Because filk is often viewed as an imitative culture, the tendency of women to depart from that ethos in creating their own melodies seems significant. It might reveal a heightened contextual sensitivity to the legal rights of others, a sensitivity also suggested by the greater number of female respondents who believed that filkers should give credit to the original authors from whom they borrow, and should not record copyrighted work without permission (Figure 11). Similarly, female respondents were much more likely to define fair use as not profiting from others' work, and somewhat more likely to define it as giving credit to the original author and making private 
as opposed to public use of a protected work (Figure 12).

Male filkers, on the other hand, offered fewer responses about how to define fair use ${ }^{139}$ while being significantly more likely to assert that they consider all legal requirements before engaging in filk activities. ${ }^{140}$ That men showed a markedly greater tendency than women to borrow the melodies of others would seem to be consistent with the imitative, competitive, and satirical impulses behind filking, and may suggest that attitudes of men and women to exploiting these impulses differ in certain respects.

Male respondents, however, were slightly less likely than female respondents to make use of the lyrics of others, i.e., slightly more likely to create their own original lyrics. ${ }^{141}$ Some of this may depend, however, on what respondents meant by "original" lyrics. Men might have been suggesting, for example, that filk lyrics that borrow from others' songs but transform those lyrics to some degree are "original" lyrics. Women might have been more reluctant to make that claim, particularly in light of their greater sensitivity to giving credit to other authors and their markedly greater tendency to define fair use as not profiting from others' work. ${ }^{142}$

We might use our Mandy example to concretize some of the foregoing suggestions. In light of the data, a female filker would be less likely than a man to use the melody of Mandy, but slightly more likely to make some use of the original lyrics, probably giving credit to Manilow. A male filker would be more likely to borrow the melody of Mandy and set it to lyrics that he would regard as "original"-whether completely or partially original, it is difficult to say-but would be less likely than a female filker, at least as a matter of fair use, to credit Manilow or to be concerned about profiting, the public nature of the performance, or recording the filk version without permission. ${ }^{143}$

Finally, because use of others' work is regarded by the filk community as a distinct type of homage, common attitudes towards infringement, piracy, and other copyright prohibitions simply may not prevail among filkers, or may be significantly inflected. The foregoing data must be viewed, at least to some extent, in the light of this communal ethos. While some filkers take a step out of the filk community by marketing recordings of their songs, it would appear that most filkers confine their activities to cons and other traditional filk settings. These traditional, insulated settings, along with the imitation-is-the-sincerest-form-of-flattery ethos prevalent

139. See supra figure 12.

140. See supra figure 11.

141. See supra figure 3.

142. See supra figures 11-12.

143. Id. 
among filkers, suggest that filkers have crafted a pastime that they regard, quite rightly perhaps, as essentially and institutionally a type of fair use. This may account, for example, for the generally low response rate to our specific questions regarding fair use. ${ }^{144}$

Because this is the first study examining the types of songs written by male and female filkers and their attitudes towards intellectual property rules, it will take some time to fully digest the results, and it may even be foolhardy at this stage to attempt to draw too many conclusions. We think that the best use of our work is as a springboard for additional empirical work targeting those areas where we found gender-related differences. Those studies should seek both to confirm (or refute) our results and to gather more information about why and how those gender-related differences arose.

144. See supra figure 12. 
APPENDIX A: SONG LYRICS

\title{
Snippin' Off His Mail
}

\author{
By: Melissa Tatum
}

I spent last night in the arms of a guy in a suit of armor and though I'm out on the highway, my thoughts are still with him Such a strange combination of a warrior and a man such a strange situation stoppin' every other kiss, snippin' off his mail.

A replay of last night's events roll through my mind Except a scene or two erased by sweet red wine I see a future tryst ahead, so I seek help I need a pair of pliers and a couple new tools for snippin' off his mail.

Armorer won't you show me the way, I gotta extract my love from his suit of mail

Hurry up won't you help me get him out, I gotta get to the man who's under hauberk

Hello, Sir Bedivere, I hope you're feelin' fine, And it won't be long until I'm with you all the time But until then I'll do some research finding me some new ways for snippin' off your mail

Armorer won't you show me the way, I gotta extract my love from his suit of mail

Hurry up won't you help me get him out, I gotta get to the man who's under hauberk

Such a strange combination of a war'or and a man such a strange situation stoppin' every other kiss, snippin' off his mail. 


\section{Urban Legend}

By: Melissa Tatum

Let me tell you the story, and I swear that it's true, of the six drunken frat boys who needed to pee

They were hazing new pledges out near the train track, so a bathroom was certainly something they lacked Their urine streams hit direct on the third rail, as they stood shocked and buzzing the train whistle wailed

Let me tell you the story, and I swear that it's true, of the newly flat penny and the six drunken frat boys who needed to pee

Two daring children were breaking curfew, so they could flatten their pennies that were shiny and new the train hit the coins and without warning it soared, straight into the van with a family on board

Let me tell you the story, and I swear that it's true, of the tiny babe trapped in the car, newly flat penny and the six drunken frat boys who needed to pee

The family was headed home from Gran's birthday, when a train came from nowhere, much to their dismay the rescuers they dug out the mom and the dad. and the next day they found something terribly sad

Let me tell you the story, and I swear that it's true, of the fireman's invention, tiny babe trapped in the car, newly flat penny, and the six drunken frat boys who needed to pee

That fireman was checking his report to complete, when he found the babe hidden underneath the back seat It survived the train crash but it died of the cold, Baby on Board signs were born, millions were sold 
Let me tell you the story, and I swear that it's true,

of the Baby on Board signs, fireman's invention, tiny babe trapped in the car,

newly flat penny, and the six drunken frat boys who needed to pee

The signs were intended to save children's lives,

and alert rescue crews who at crash scenes arrive

so that never again would babes be ignored,

but instead people laughed and made signs casting scorn

they said Baby is Driving

And they said Husband is in Trunk

And they said Baby is Closer than it Appears

And suddenly a man found a use for orange kittens and those

leftover suction cup doohickeys creating a brand new cottage industry whose unlikely social repercussions triggered a really stupid new fad!

Ohhhhh!

And that was the story, the urban legend... of the Garfield-covered passenger side windows, the yellow baby parody sign things, Baby on Board signs, fireman's invention, tiny babe trapped in the car, newly flat penny, and the six drunken frat boys who needed to pee 


\title{
Paksenarrion
}

\author{
By: Melissa L. Tatum
}

Just look at you, Paksenarrion

lowly farm girl, now a paladin - touched by Gird

He safeguards you, Paksenarrion

as you wander answering his call

near and far, near and far

She dreams of armies, soldiering, adventures, so much more

She hungers for a very different life

Run away, Paks, you'll fulfill those burning, questing dreams

Start your life a-new, prepare to shed the old

Just look at you, Paksenarrion

lowly farm girl, now a paladin - touched by Gird

He safeguards you, Paksenarrion

as you wander answering his call

near and far, near and far

Army life was quite a bit more mundane than she thought

Digging latrines wasn't part of her dreams

But the mercenaries gave her the training that she needs

Time to move on to the next stage of her life

Just look at you, Paksenarrion

lowly farm girl, now a paladin - touched by Gird

He safeguards you, Paksenarrion

as you wander answering his call

near and far, near and far

Evil lurks in darkened places sinking secret roots weaving webs of tangled wicked plans

It's the duty of the just to shine the light of truth

Burn away, disrupt the tainted strands

We call on you, Paksenarrion

lowly farm girl, now a paladin - touched by Gird 
You safeguard us, Paksenarrion

as you wander answering Gird's call near and far, near and far 


\section{APPENDIX B*}

\section{Song Database}

Gender and Co-Author

Actual numbers:

\begin{tabular}{|l|l|l|l|l|}
\hline & Female & Male & None & Unk \\
\hline Female & 15 & 10 & 286 & 2 \\
\hline Male & 22 & 22 & 536 & 0 \\
\hline Transgender & 0 & 0 & 2 & 0 \\
\hline
\end{tabular}

Percentages:

\begin{tabular}{|l|l|l|l|l|}
\hline & Female & Male & None & Unk \\
\hline Female & 4.8 & 3.2 & 91.4 & 0.6 \\
\hline Male & 3.8 & 3.8 & 92.4 & 0 \\
\hline Transgender & 0 & 0 & 100 & 0 \\
\hline
\end{tabular}

Pearson's Chi-squared test

$\mathrm{X}$-squared $=4.6054$

$\mathrm{df}=6, \mathrm{p}$-value $=0.5953$

Thus, we conclude that a person's gender is independent of whether they have a male, female or unknown coauthor.

Appendices B and D contain the raw data and statistical analysis from our surveys. We include them for the benefit of those who desire access to that data. 
Gender and Lyrics

Actual numbers:

\begin{tabular}{|l|l|l|}
\hline & $\begin{array}{l}\text { Completely } \\
\text { original }\end{array}$ & $\begin{array}{l}\text { Using another's } \\
\text { characters/universe }\end{array}$ \\
\hline Female & 171 & 142 \\
\hline Male & 361 & 219 \\
\hline Transgender & 1 & 1 \\
\hline
\end{tabular}

Percentages:

\begin{tabular}{|l|l|l|}
\hline & $\begin{array}{l}\text { Completely } \\
\text { original }\end{array}$ & $\begin{array}{l}\text { Using another's } \\
\text { characters/universe }\end{array}$ \\
\hline Female & 54.6 & 45.4 \\
\hline Male & 62.2 & 37.8 \\
\hline Transgender & 50.0 & 50.0 \\
\hline
\end{tabular}

Pearson's Chi-squared test

$\mathrm{X}$-squared $=4.962$

$\mathrm{df}=2, \mathrm{p}$-value $=0.08366$

Thus, we conclude that there is weak evidence of dependence between a writer's gender and whether their lyrics are completely original or uses another's characters or universe. 
Gender and Melody

Actual numbers:

\begin{tabular}{|l|l|l|l|l|}
\hline & Orig. & Copyrt & $\begin{array}{l}\text { Other } \\
\text { filker }\end{array}$ & $\begin{array}{l}\text { Public } \\
\text { domain }\end{array}$ \\
\hline Female & 94 & 110 & 61 & 48 \\
\hline Male & 124 & 235 & 146 & 75 \\
\hline Transg. & 1 & 1 & 0 & 0 \\
\hline
\end{tabular}

Percentages:

\begin{tabular}{|l|l|l|l|l|}
\hline & Orig. & Copyrt & $\begin{array}{l}\text { Other } \\
\text { filker }\end{array}$ & $\begin{array}{l}\text { Public } \\
\text { domain }\end{array}$ \\
\hline Female & 30.0 & 35.1 & 19.5 & 15.3 \\
\hline Male & 21.4 & 40.5 & 25.2 & 12.9 \\
\hline Transg & 50.0 & 50.0 & 0 & 0 \\
\hline
\end{tabular}

Pearson's Chi-squared test

$\mathrm{X}$-squared $=12.7727$

$\mathrm{df}=6, \mathrm{p}$-value $=0.04679$

Thus, we conclude that gender and the type of melody used are dependent. 
Gender and Years/Rates of Publication

Actual numbers:

\begin{tabular}{|l|l|l|l|l|l|l|l|}
\hline & $\begin{array}{l}1983- \\
87\end{array}$ & $\begin{array}{l}1988- \\
1992\end{array}$ & $\begin{array}{l}1993- \\
97\end{array}$ & $\begin{array}{l}1998- \\
2002\end{array}$ & $\begin{array}{l}2003- \\
07\end{array}$ & $\begin{array}{l}2008- \\
\text { present }\end{array}$ & none \\
\hline Female & 1 & 62 & 73 & 30 & 31 & 30 & 86 \\
\hline Male & 0 & 65 & 116 & 103 & 114 & 78 & 104 \\
\hline Transgender & 0 & 0 & 0 & 0 & 1 & 0 & 1 \\
\hline
\end{tabular}

Percentages:

\begin{tabular}{|l|l|l|l|l|l|l|l|}
\hline & $\begin{array}{l}1983- \\
87\end{array}$ & $\begin{array}{l}1988- \\
1992\end{array}$ & $\begin{array}{l}1993- \\
97\end{array}$ & $\begin{array}{l}1998- \\
2002\end{array}$ & $\begin{array}{l}2003- \\
07\end{array}$ & $\begin{array}{l}2008- \\
\text { present }\end{array}$ & none \\
\hline Female & 0.3 & 19.8 & 23.3 & 9.6 & 9.9 & 9.6 & 27.5 \\
\hline Male & 0 & 11.2 & 20.0 & 17.8 & 19.7 & 13.4 & 17.9 \\
\hline Transgender & 0 & 0 & 0 & 0 & 50.0 & 0 & 50.0 \\
\hline
\end{tabular}

Pearson's Chi-squared test

$\mathrm{X}$-squared $=49.1182, \mathrm{df}=12, \mathrm{p}$-value $=1.994 \mathrm{e}-06$

Thus, we conclude that the gender of the author and whether (and when) an author has been published in Xenofilkia are dependent. 
Gender and Pegasus Nominations

Actual numbers:

\begin{tabular}{|l|l|l|l|l|l|l|l|l|}
\hline & Multiple & $\begin{array}{l}1983- \\
1987\end{array}$ & $\begin{array}{l}1998- \\
1992\end{array}$ & $\begin{array}{l}1993- \\
1997\end{array}$ & $\begin{array}{l}1998- \\
2002\end{array}$ & $\begin{array}{l}2003- \\
2007\end{array}$ & $\begin{array}{l}2008- \\
\text { present }\end{array}$ & None \\
\hline Female & 19 & 6 & 10 & 12 & 14 & 16 & 3 & 233 \\
\hline Male & 20 & 5 & 9 & 13 & 13 & 29 & 2 & 489 \\
\hline Transgender & 0 & 0 & 0 & 1 & 0 & 0 & 0 & 1 \\
\hline
\end{tabular}

Percentages:

\begin{tabular}{|l|l|l|l|l|l|l|l|l|}
\hline & Multiple & $\begin{array}{l}1983- \\
1987\end{array}$ & $\begin{array}{l}1998- \\
1992\end{array}$ & $\begin{array}{l}1993- \\
1997\end{array}$ & $\begin{array}{l}1998- \\
2002\end{array}$ & $\begin{array}{l}2003- \\
2007\end{array}$ & $\begin{array}{l}2008- \\
\text { present }\end{array}$ & None \\
\hline Female & 6.1 & 1.9 & 3.2 & 3.8 & 4.5 & 5.1 & 1.0 & 74.4 \\
\hline Male & 3.4 & 0.9 & 1.6 & 2.2 & 2.2 & 5.0 & 0.3 & 84.3 \\
\hline Transgender & 0 & 0 & 0 & 50.0 & 0 & 0 & 0 & 50.0 \\
\hline
\end{tabular}

Pearson's Chi-squared test:

$\mathrm{X}$-squared $=32.4562, \mathrm{df}=14, \mathrm{p}$-value $=0.003449$

Thus, whether (and when) an author has been nominated for Pegasus and their gender are dependent variables. 


\section{APPENDIX C: SURVEY INSTRUMENT}

1. What is your gender? (male, female, transgender)

2. How long have you been involved in filk? (less than 1 year; $1-5$ years; 6-10 years; $11-15$ years; $16-20$ years; more than 20 years)

3. What age group do you fall into $(18-30 ; 31-40 ; 41-50$; over 50$)$ ?

4. What is the highest degree you hold (HS Diploma, College Degree, Graduate degree)?

5. Which category best describes how you make your living (artist; clerical; management; musician; sales/marketing; student; educator; technical; other)?

6. In which country do you reside? (Canada, UK, USA, Other)

7. Which of the following apply to you? (Check all that apply):

- I have written new lyrics for existing melodies

- I have written lyrics based on characters/worlds created by another person

- I have written songs with original lyrics and original melodies

- I have performed songs written by another person

- I have recorded songs written by other people

- I have recorded songs containing lyrics I wrote set to an existing melody

- I have recorded songs containing lyrics I wrote based on characters/worlds created by another person

- I have recorded songs with original lyrics and original melodies

8. If you write songs, what (if any) intellectual property considerations do you think about?

9. If you perform songs, what (if any) intellectual property considerations do you think about?

10. If you record songs, what (if any) intellectual property considerations do you think about? 
JOURNAL OF GeNDER, SOCIAL POLICY \& THE LAW [Vol. 18:2

11. How do you define fair use/fair dealing of copyrighted works?

12. What is your opinion of current copyright laws?

13. Have you ever registered a copyright for any work?

14. Have you ever registered a copyright for a filk-related work?

15. Do you participate in Creative Commons? 
APPENDIX D

Gender and Length of Involvement (measured in years)

Actual numbers:

\begin{tabular}{|l|l|l|l|l|l|}
\hline & $\begin{array}{l}1-5 \\
\text { yrs }\end{array}$ & $\begin{array}{l}6-10 \\
\text { yrs }\end{array}$ & $\begin{array}{l}11-15 \\
\text { yrs }\end{array}$ & $\begin{array}{l}16-20 \\
\text { yrs }\end{array}$ & $\begin{array}{l}\text { more } \\
\text { than } \\
20 \text { yrs }\end{array}$ \\
\hline Fem & 7 & 8 & 2 & 6 & 10 \\
\hline Male & 4 & 6 & 5 & 3 & 11 \\
\hline
\end{tabular}

Percentages:

\begin{tabular}{|l|l|l|l|l|l|}
\hline & $\begin{array}{l}1-5 \\
\text { yrs }\end{array}$ & $\begin{array}{l}6-10 \\
\text { yrs }\end{array}$ & $\begin{array}{l}11-15 \\
\text { yrs }\end{array}$ & $\begin{array}{l}16-20 \\
\text { yrs }\end{array}$ & $\begin{array}{l}\text { more } \\
\text { than } \\
20 \text { yrs }\end{array}$ \\
\hline Fem & 21.2 & 24.2 & 6.1 & 18.2 & 30.3 \\
\hline Male & 13.8 & 20.7 & 17.2 & 10.3 & 37.9 \\
\hline
\end{tabular}

Pearson's Chi-squared test

$\mathrm{X}$-squared $=3.1925$

$\mathrm{df}=4$, $\mathrm{p}$-value $=0.5262$

Thus we conclude that gender and length of involvement in filk are independent. 
Gender and Age

Actual numbers:

\begin{tabular}{|l|l|l|l|l|l|}
\hline & $18-30$ & $31-40$ & $41-50$ & $\begin{array}{l}\text { Over } \\
50\end{array}$ & $\begin{array}{l}\text { No } \\
\text { Answer }\end{array}$ \\
\hline Fem & 8 & 8 & 6 & 10 & 1 \\
\hline Male & 6 & 6 & 5 & 12 & 0 \\
\hline
\end{tabular}

Percentages:

\begin{tabular}{|l|l|l|l|l|l|}
\hline & $18-30$ & $31-40$ & $41-50$ & $\begin{array}{l}\text { Over } \\
50\end{array}$ & $\begin{array}{l}\text { No } \\
\text { Answer }\end{array}$ \\
\hline Fem & 24.2 & 24.2 & 18.2 & 30.3 & 3.0 \\
\hline Male & 20.7 & 20.7 & 17.2 & 41.4 & 0 \\
\hline
\end{tabular}

Pearson's Chi-squared test

$\mathrm{X}$-squared $=1.5927$

$\mathrm{df}=4$, $\mathrm{p}$-value $=0.8101$

Thus we conclude that gender and age are independent.

Gender and Education Level

Actual numbers:

\begin{tabular}{|l|l|l|l|l|}
\hline & H.S./GED & College & Graduate & $\begin{array}{l}\text { No } \\
\text { Answer }\end{array}$ \\
\hline Fem & 4 & 15 & 13 & 1 \\
\hline Male & 4 & 12 & 12 & 1 \\
\hline
\end{tabular}

Percentages:

\begin{tabular}{|l|l|l|l|l|}
\hline & H.S./GED & College & Graduate & $\begin{array}{l}\text { No } \\
\text { Answer }\end{array}$ \\
\hline Fem & 12.1 & 45.5 & 39.4 & 3.0 \\
\hline Male & 13.8 & 41.4 & 41.4 & 3.4 \\
\hline
\end{tabular}

Pearson's Chi-squared test

$\mathrm{X}$-squared $=0.1158$

$\mathrm{df}=3$, p-value $=0.9899$.

Thus we conclude that gender and education level are independent. 
Gender and Occupation

Actual numbers:

\begin{tabular}{|l|l|l|l|l|l|l|l|l|l|l|l|}
\hline & Art & Cleric. & Mgmt & Music & Wrtr. & $\begin{array}{l}\text { Sales/ } \\
\text { Mktg }\end{array}$ & Stud. & Teach & Tech. & Other & $\begin{array}{l}\text { No } \\
\text { Ans }\end{array}$ \\
\hline F & 3 & 2 & 3 & 2 & 2 & 1 & 4 & 1 & 5 & 10 & 0 \\
\hline M & 1 & 0 & 2 & 0 & 0 & 2 & 2 & 1 & 18 & 2 & 1 \\
\hline
\end{tabular}

Percentages:

\begin{tabular}{|l|l|l|l|l|l|l|l|l|l|l|l|}
\hline & Art & Cleric. & Mgmt & Music & Wrtr. & $\begin{array}{l}\text { Sales/ } \\
\text { Mktg }\end{array}$ & Stud. & Teach & Tech & Other & $\begin{array}{l}\text { No } \\
\text { Ans }\end{array}$ \\
\hline F & 9.1 & 6.1 & 9.1 & 6.1 & 6.1 & 3.0 & 12.1 & 3.0 & 15.2 & 30.3 & 0 \\
\hline M & 3.4 & 0 & 6.9 & 0 & 0 & 6.9 & 6.9 & 3.4 & 62.1 & 6.9 & 3.4 \\
\hline
\end{tabular}

Pearson's Chi-squared test

$\mathrm{X}$-squared $=21.7135, \mathrm{df}=10, \mathrm{p}$-value $=0.01663$.

Thus we conclude that gender and occupation are strongly dependent.

Gender vs. Nationality

Actual numbers:

\begin{tabular}{|l|l|l|l|l|}
\hline & Canada & $\begin{array}{l}\text { United } \\
\text { States }\end{array}$ & $\begin{array}{l}\text { United } \\
\text { Kingdom }\end{array}$ & Other \\
\hline Female & 1 & 29 & 3 & 0 \\
\hline Male & 1 & 27 & 0 & 1 \\
\hline
\end{tabular}

Percentages:

\begin{tabular}{|l|l|l|l|l|}
\hline & Canada & $\begin{array}{l}\text { United } \\
\text { States }\end{array}$ & $\begin{array}{l}\text { United } \\
\text { Kingdom }\end{array}$ & Other \\
\hline Female & 3.0 & 87.9 & 9.1 & 0 \\
\hline Male & 3.4 & 93.1 & 0 & 3.4 \\
\hline
\end{tabular}

Pearson's Chi-squared test

$\mathrm{X}$-squared $=3.8293$

$\mathrm{df}=3$, p-value $=0.2805>.05$.

Thus we conclude that gender and nationality are independent. 
Gender and writing new lyrics to existing melody Actual numbers:

\begin{tabular}{|l|l|l|l|}
\hline & No & Yes & No Response \\
\hline Female & 4 & 29 & 0 \\
\hline Male & 2 & 26 & 1 \\
\hline
\end{tabular}

Percentages:

\begin{tabular}{|l|l|l|l|}
\hline & No & Yes & No Response \\
\hline Female & 12.1 & 87.9 & 0 \\
\hline Male & 6.9 & 89.7 & 3.4 \\
\hline
\end{tabular}

Pearson's Chi-squared test

$\mathrm{X}$-squared $=1.5788$

$\mathrm{df}=2, \mathrm{p}$-value $=0.4541$

Thus we conclude that whether someone has written new lyrics to an existing melody is independent of their gender.

Gender and writing lyrics based on existing characters

Actual numbers:

\begin{tabular}{|l|l|l|l|}
\hline & No & Yes & No Response \\
\hline Female & 9 & 24 & 0 \\
\hline Male & 7 & 21 & 1 \\
\hline
\end{tabular}

Percentages:

\begin{tabular}{|l|l|l|l|}
\hline & No & Yes & No Response \\
\hline Female & 27.3 & 72.7 & 0 \\
\hline Male & 24.1 & 72.4 & 3.4 \\
\hline
\end{tabular}

Pearson's Chi-squared test

$\mathrm{X}$-squared $=1.1969, \mathrm{df}=2, \mathrm{p}$-value $=0.5497$.

Thus we conclude that whether someone has written lyrics based on characters or worlds

created by another person is independent of their gender. 
Gender and writing original lyrics, original melody Actual numbers:

\begin{tabular}{|l|l|l|l|}
\hline & No & Yes & No Response \\
\hline Female & 13 & 20 & 1 \\
\hline Male & 7 & 21 & 1 \\
\hline
\end{tabular}

Percentages:

\begin{tabular}{|l|l|l|l|}
\hline & No & Yes & No Response \\
\hline Female & 39.4 & 60.6 & 0 \\
\hline Male & 24.1 & 72.4 & 3.4 \\
\hline
\end{tabular}

Pearson's Chi-squared test

$\mathrm{X}$-squared $=3.561, \mathrm{df}=2, \mathrm{p}$-value $=0.1686$

Thus we conclude that gender is independent of whether someone has recorded songs with original lyrics and original melody.

Gender and performing songs written by another person Actual numbers:

\begin{tabular}{|l|l|l|l|}
\hline & No & Yes & No Response \\
\hline Female & 6 & 27 & 0 \\
\hline Male & 1 & 26 & 2 \\
\hline
\end{tabular}

Percentages:

\begin{tabular}{|l|l|l|l|}
\hline & No & Yes & No Response \\
\hline Female & 18.2 & 81.8 & 0 \\
\hline Male & 3.4 & 89.7 & 6.9 \\
\hline
\end{tabular}

Pearson's Chi-squared test

$X$-squared $=5.3545, \mathrm{df}=2, \mathrm{p}$-value $=0.06875$.

Thus we conclude that whether someone has performed songs written by another person is independent of their gender. 
Gender and recording songs written by another person

Actual numbers:

\begin{tabular}{|l|l|l|l|}
\hline & No & Yes & No Response \\
\hline Female & 23 & 10 & 0 \\
\hline Male & 16 & 12 & 1 \\
\hline
\end{tabular}

Percentages:

\begin{tabular}{|l|l|l|l|}
\hline & No & Yes & No Response \\
\hline Female & 69.7 & 30.3 & 0 \\
\hline Male & 55.2 & 41.4 & 3.4 \\
\hline
\end{tabular}

Pearson's Chi-squared test

$\mathrm{X}$-squared $=2.1893, \mathrm{df}=2, \mathrm{p}$-value $=0.3347$

Thus we conclude gender is independent of whether someone has recorded songs written by another person.

Gender and recording songs with original lyrics written to existing melody

Actual numbers:

\begin{tabular}{|l|l|l|l|}
\hline & No & Yes & No Response \\
\hline Female & 26 & 7 & 0 \\
\hline Male & 16 & 12 & 1 \\
\hline
\end{tabular}

Percentages:

\begin{tabular}{|l|l|l|l|}
\hline & No & Yes & No Response \\
\hline Female & 78.8 & 21.2 & 0 \\
\hline Male & $55 . .2$ & 41.4 & 3.4 \\
\hline
\end{tabular}

Pearson's Chi-squared test

$X$-squared $=4.4572, \mathrm{df}=2, \mathrm{p}$-value $=0.1077$

Thus we conclude that gender is independent of whether someone has recorded songs with

lyrics he/she wrote to an existing melody. 
Gender and recording songs with lyrics using characters/worlds created by another person

Actual numbers:

\begin{tabular}{|l|l|l|l|}
\hline & No & Yes & No Response \\
\hline Female & 28 & 5 & 0 \\
\hline Male & 20 & 8 & 1 \\
\hline
\end{tabular}

Percentages:

\begin{tabular}{|l|l|l|l|}
\hline & No & Yes & No Response \\
\hline Female & 84.8 & 15.2 & 0 \\
\hline Male & 69.0 & 27.6 & 3.4 \\
\hline
\end{tabular}

Pearson's Chi-squared test

$\mathrm{X}$-squared $=2.7791, \mathrm{df}=2, \mathrm{p}$-value $=0.2492$

Thus, we concluded that whether someone has recorded songs with lyrics he/she wrote using characters or worlds created by another person is independent of their gender.

Gender and recording songs with original lyrics and original melody Actual numbers:

\begin{tabular}{|l|l|l|l|}
\hline & No & Yes & No Response \\
\hline Female & 24 & 9 & 0 \\
\hline Male & 15 & 13 & 1 \\
\hline
\end{tabular}

Percentages:

\begin{tabular}{|l|l|l|l|}
\hline & No & Yes & No Response \\
\hline Female & 72.7 & 27.3 & 0 \\
\hline Male & 51.7 & 44.8 & 3.4 \\
\hline
\end{tabular}

Pearson's Chi-squared test

$\mathrm{X}$-squared $=3.561, \mathrm{df}=2, \mathrm{p}$-value $=0.1686$

Thus, gender is independent of whether someone has recorded songs with original lyrics and original melody. 
Gender and whether registered a copyright

Actual numbers:

\begin{tabular}{|l|l|l|l|}
\hline & No & Yes & No Response \\
\hline Female & 28 & 4 & 1 \\
\hline Male & 23 & 6 & 0 \\
\hline
\end{tabular}

Percentages:

\begin{tabular}{|l|l|l|l|}
\hline & No & Yes & No Response \\
\hline Female & 84.8 & 12.1 & 3.0 \\
\hline Male & 79.3 & 20.7 & 0 \\
\hline
\end{tabular}

Pearson's Chi-squared test

$\mathrm{X}$-squared $=1.639, \mathrm{df}=2, \mathrm{p}$-value $=0.4407$

Thus, we conclude that whether someone has registered a copyright for any work is independent of their gender.

Gender and whether registered a copyright for a filk-related work Actual numbers:

\begin{tabular}{|l|l|l|l|}
\hline & No & Yes & No Response \\
\hline Female & 30 & 1 & 2 \\
\hline Male & 28 & 1 & 0 \\
\hline
\end{tabular}

Percentages:

\begin{tabular}{|l|l|l|l|}
\hline & No & Yes & No Response \\
\hline Female & 90.9 & 3.0 & 6.1 \\
\hline Male & 96.6 & 3.4 & 0 \\
\hline
\end{tabular}

Pearson's Chi-squared test

$\mathrm{X}$-squared $=1.8185, \mathrm{df}=2, \mathrm{p}$-value $=0.4028$

Thus, we conclude that someone's gender is independent of whether they have ever registered a copyright for a filk-related work. 
Gender and whether participated in Creative Commons Actual numbers:

\begin{tabular}{|l|l|l|l|}
\hline & No & Yes & No Response \\
\hline Female & 26 & 6 & 1 \\
\hline Male & 16 & 13 & 0 \\
\hline
\end{tabular}

Percentages:

\begin{tabular}{|l|l|l|l|}
\hline & No & Yes & No Response \\
\hline Female & 78.8 & 18.2 & 3.0 \\
\hline Male & 55.2 & 44.8 & 0 \\
\hline
\end{tabular}

Pearson's Chi-squared test

$X$-squared $=5.7257, \mathrm{df}=2, \mathrm{p}$-value $=0.05711$

Thus, we conclude that whether someone has participated in Creative Commons is independent of their gender.

Gender and whether should credit original author Actual numbers:

\begin{tabular}{|l|l|l|}
\hline & No & Yes \\
\hline Female & 18 & 15 \\
\hline Male & 18 & 11 \\
\hline
\end{tabular}

Percentages:

\begin{tabular}{|l|l|l|}
\hline & No & Yes \\
\hline Female & 54.5 & 45.5 \\
\hline Male & 62.1 & 37.9 \\
\hline
\end{tabular}

Pearson's Chi-squared test with Yates' continuity correction $\mathrm{X}$-squared $=0.1164, \mathrm{df}=1, \mathrm{p}$-value $=0.733$

Thus, we conclude that gender is independent of believing that one should credit the author of a work. 
Gender and whether should ask before using others' work

Actual numbers:

\begin{tabular}{|l|l|l|}
\hline & No & Yes \\
\hline Female & 33 & 0 \\
\hline Male & 27 & 2 \\
\hline
\end{tabular}

Percentages:

\begin{tabular}{|l|l|l|}
\hline & No & Yes \\
\hline Female & 100 & 0 \\
\hline Male & 93.1 & 6.9 \\
\hline
\end{tabular}

Pearson's Chi-squared test with Yates' continuity correction $\mathrm{X}$-squared $=0.6614, \mathrm{df}=1, \mathrm{p}$-value $=0.4161$

Thus, one concludes that the belief that one should ask before using others' work is independent of gender.

Gender and whether try to use only tunes that are original in public domain

Actual numbers:

Percentages:

\begin{tabular}{|l|l|l|}
\hline & No & Yes \\
\hline Female & 29 & 4 \\
\hline Male & 25 & 4 \\
\hline
\end{tabular}

\begin{tabular}{|l|l|l|}
\hline & No & Yes \\
\hline Female & 87.9 & 12.1 \\
\hline Male & 86.2 & 13.8 \\
\hline
\end{tabular}

Pearson's Chi-squared test with Yates' continuity correction $\mathrm{X}$-squared $=0.0337, \mathrm{df}=1, \mathrm{p}$-value $=0.8543$

Thus, we conclude that only using tunes that are original in the public domain and gender are independent. 
Gender and whether there is no problem so long as don't earn money Actual numbers:

\begin{tabular}{|l|l|l|}
\hline & No & Yes \\
\hline Female & 29 & 4 \\
\hline Male & 23 & 6 \\
\hline
\end{tabular}

Percentages:

\begin{tabular}{|l|l|l|}
\hline & No & Yes \\
\hline Female & 87.8 & 12.1 \\
\hline Male & 79.3 & 20.7 \\
\hline
\end{tabular}

Pearson's Chi-squared test with Yates' continuity correction $\mathrm{X}$-squared $=0.3241, \mathrm{df}=1, \mathrm{p}$-value $=0.5692$

Thus, we conclude that gender and the belief that there is no problem if the user does not earn money are independent.

Gender and whether there's no problem if don't perform publicly Actual numbers:

\begin{tabular}{|l|l|l|}
\hline & No & Yes \\
\hline Female & 29 & 4 \\
\hline Male & 27 & 2 \\
\hline
\end{tabular}

Percentages:

\begin{tabular}{|l|l|l|}
\hline & No & Yes \\
\hline Female & 87.9 & 12.1 \\
\hline Male & 93.1 & 6.9 \\
\hline
\end{tabular}

Pearson's Chi-squared test with Yates' continuity correction $\mathrm{X}$-squared $=0.0696, \mathrm{df}=1, \mathrm{p}$-value $=0.7919$

Thus, we conclude that gender is independent of the belief that there is no problem if the user does not perform publicly. 
Gender and "I don't worry about it because I perform only in informal song circles"

Actual numbers:

\begin{tabular}{|l|l|l|}
\hline & No & Yes \\
\hline Female & 26 & 7 \\
\hline Male & 19 & 10 \\
\hline
\end{tabular}

Percentages:

\begin{tabular}{|l|l|l|}
\hline & No & Yes \\
\hline Female & 78.8 & 21.2 \\
\hline Male & 65.5 & 34.5 \\
\hline
\end{tabular}

Pearson's Chi-squared test with Yates' continuity correction $\mathrm{X}$-squared $=0.7805, \mathrm{df}=1, \mathrm{p}$-value $=0.377$

Thus, we conclude that gender is independent of those who are not concerned about intellectual property because they only perform in informal song circles.

Gender and "I don't record copyrighted works without permission" Actual numbers:

\begin{tabular}{|l|l|l|}
\hline & No & Yes \\
\hline Female & 23 & 10 \\
\hline Male & 22 & 7 \\
\hline
\end{tabular}

Percentages:

\begin{tabular}{|l|l|l|}
\hline & No & Yes \\
\hline Female & 68.7 & 30.3 \\
\hline Male & 75.9 & 24.1 \\
\hline
\end{tabular}

Pearson's Chi-squared test with Yates' continuity correction $X$-squared $=0.0664, \mathrm{df}=1, \mathrm{p}$-value $=0.7967$

Thus, we conclude that gender is independent of not recording copyrighted works without permission. 
Gender and "I consider all legal requirements"

Actual numbers:

\begin{tabular}{|l|l|l|}
\hline & No & Yes \\
\hline Female & 33 & 0 \\
\hline Male & 24 & 5 \\
\hline
\end{tabular}

Percentages:

\begin{tabular}{|l|l|l|}
\hline & No & Yes \\
\hline Female & 100 & 0 \\
\hline Male & 82.8 & 17.2 \\
\hline
\end{tabular}

Pearson's Chi-squared test with Yates' continuity correction $X$-squared $=4.0817, \mathrm{df}=1, \mathrm{p}$-value $=0.04335$

Thus, we conclude that gender and whether someone considers all legal requirements are strongly dependent.

Gender and "I try not to think about all the laws being violated" Actual numbers:

Percentages:

\begin{tabular}{|l|l|l|}
\hline & No & Yes \\
\hline Female & 32 & 1 \\
\hline Male & 29 & 0 \\
\hline
\end{tabular}

\begin{tabular}{|l|l|l|}
\hline & No & Yes \\
\hline Female & 97.0 & 3.0 \\
\hline Male & 100 & 0 \\
\hline
\end{tabular}

Pearson's Chi-squared test with Yates' continuity correction $\mathrm{X}$-squared $=0.0042, \mathrm{df}=1, \mathrm{p}$-value $=0.948$

Thus, we conclude that gender and whether someone tries not to think about all the laws he/she is violating are independent. 
Gender and current copyright laws are outdated Actual numbers:

\begin{tabular}{|l|l|l|}
\hline & $\begin{array}{l}\text { No/No } \\
\text { Response }\end{array}$ & Yes \\
\hline Female & 30 & 3 \\
\hline Male & 22 & 7 \\
\hline
\end{tabular}

Percentages:

\begin{tabular}{|l|l|l|}
\hline & $\begin{array}{l}\text { No/No } \\
\text { Response }\end{array}$ & Yes \\
\hline Female & 90.9 & 9.1 \\
\hline Male & 75.9 & 24.1 \\
\hline
\end{tabular}

Pearson's Chi-squared test with Yates' continuity correction $\mathrm{X}$-squared $=1.5909, \mathrm{df}=1, \mathrm{p}$-value $=0.2072$

Thus, we conclude that gender and whether someone believes copyright laws to be outdated are independent.

Gender and Current copyright law is irrelevant in light of technology Actual numbers:

\begin{tabular}{|l|l|l|}
\hline & $\begin{array}{l}\text { No/No } \\
\text { Response }\end{array}$ & Yes \\
\hline Female & 31 & 2 \\
\hline Male & 25 & 4 \\
\hline
\end{tabular}

Percentages:

\begin{tabular}{|l|l|l|}
\hline & $\begin{array}{l}\text { No/No } \\
\text { Response }\end{array}$ & Yes \\
\hline Female & 93.9 & 6.1 \\
\hline Male & 86.2 & 13.8 \\
\hline
\end{tabular}

Pearson's Chi-squared test with Yates' continuity correction $\mathrm{X}$-squared $=0.3565, \mathrm{df}=1, \mathrm{p}$-value $=0.5504$

Thus, we conclude that believing copyright laws are irrelevant in light of technology and gender are independent. 
Gender and copyright lasts too long

Actual numbers:

\begin{tabular}{|l|l|l|}
\hline & $\begin{array}{l}\text { No/No } \\
\text { Response }\end{array}$ & Yes \\
\hline Female & 25 & 8 \\
\hline Male & 14 & 15 \\
\hline
\end{tabular}

Percentages:

\begin{tabular}{|l|l|l|}
\hline & $\begin{array}{l}\text { No/No } \\
\text { Response }\end{array}$ & Yes \\
\hline Female & 75.8 & 24.2 \\
\hline Male & 48.3 & 51.7 \\
\hline
\end{tabular}

Pearson's Chi-squared test with Yates' continuity correction

$\mathrm{X}$-squared $=3.8874, \mathrm{df}=1, \mathrm{p}$-value $=0.04865$

Thus, we conclude that gender and whether someone believes copyright lasts too long are strongly significant.

Gender and "I don't know enough to form opinion about current copyright law"

Actual numbers:

\begin{tabular}{|l|l|l|}
\hline & $\begin{array}{l}\text { No/No } \\
\text { Response }\end{array}$ & Yes \\
\hline Female & 26 & 7 \\
\hline Male & 28 & 1 \\
\hline
\end{tabular}

Percentages:

\begin{tabular}{|l|l|l|}
\hline & $\begin{array}{l}\text { No/No } \\
\text { Response }\end{array}$ & Yes \\
\hline Female & 78.8 & 21.2 \\
\hline Male & 96.6 & 3.4 \\
\hline
\end{tabular}

Pearson's Chi-squared test with Yates' continuity correction

$\mathrm{X}$-squared $=2.8975, \mathrm{df}=1, \mathrm{p}$-value $=0.08872$

Thus, we conclude that gender and whether someone does not know enough about copyright laws are weakly dependent. 
Gender and penalties are too severe

Actual numbers:

\begin{tabular}{|l|l|l|}
\hline & $\begin{array}{l}\text { No/No } \\
\text { Response }\end{array}$ & Yes \\
\hline Female & 31 & 2 \\
\hline Male & 27 & 2 \\
\hline
\end{tabular}

Percentages:

\begin{tabular}{|l|l|l|}
\hline & $\begin{array}{l}\text { No/No } \\
\text { Response }\end{array}$ & Yes \\
\hline Female & 93.9 & 6.1 \\
\hline Male & 93.1 & 6.9 \\
\hline
\end{tabular}

Pearson's Chi-squared test with Yates' continuity correction $\mathrm{X}$-squared $=0.1477, \mathrm{df}=1, \mathrm{p}$-value $=0.7007$

Thus, we conclude that gender is independent of believing that the penalties are too severe.

Gender and current copyright law works fine Actual numbers:

\begin{tabular}{|l|l|l|}
\hline & $\begin{array}{l}\text { No/No } \\
\text { Response }\end{array}$ & Yes \\
\hline Female & 28 & 5 \\
\hline Male & 26 & 3 \\
\hline
\end{tabular}

Percentages:

\begin{tabular}{|l|l|l|}
\hline & $\begin{array}{l}\text { No/No } \\
\text { Response }\end{array}$ & Yes \\
\hline Female & 84.8 & 15.2 \\
\hline Male & 89.7 & 10.3 \\
\hline
\end{tabular}

Pearson's Chi-squared test with Yates' continuity correction $X$-squared $=0.0337, \mathrm{df}=1, \mathrm{p}$-value $=0.8543$

Thus, gender is independent of believing that the copyright laws work fine. 
Gender and copyright law gives too much control to corporations rather than individual creator

Actual numbers:

\begin{tabular}{|l|l|l|}
\hline & $\begin{array}{l}\text { No/No } \\
\text { Response }\end{array}$ & Yes \\
\hline Female & 29 & 4 \\
\hline Male & 24 & 5 \\
\hline
\end{tabular}

Percentages:

\begin{tabular}{|l|l|l|}
\hline & $\begin{array}{l}\text { No/No } \\
\text { Response }\end{array}$ & Yes \\
\hline Female & 87.9 & 12.1 \\
\hline Male & 82.8 & 17.2 \\
\hline
\end{tabular}

Pearson's Chi-squared test with Yates' continuity correction $\mathrm{X}$-squared $=0.044, \mathrm{df}=1, \mathrm{p}$-value $=0.8338$

Thus, gender is independent of the belief that copyright laws give too much control to corporations as opposed to individual creators.

Gender vs. copyright law is too limiting/some degree of use promotes market for original

Actual numbers:

\begin{tabular}{|l|l|l|}
\hline & $\begin{array}{l}\text { No/No } \\
\text { Response }\end{array}$ & Yes \\
\hline Female & 30 & 3 \\
\hline Male & 29 & 0 \\
\hline
\end{tabular}

Percentages:

\begin{tabular}{|l|l|l|}
\hline & $\begin{array}{l}\text { No/No } \\
\text { Response }\end{array}$ & Yes \\
\hline Female & 90.9 & 9.1 \\
\hline Male & 100.0 & 0 \\
\hline
\end{tabular}

Pearson's Chi-squared test with Yates' continuity correction $\mathrm{X}$-squared $=1.1478, \mathrm{df}=1, \mathrm{p}$-value $=0.284$

Thus, the belief that copyright laws are too limiting, and that some degree of use promotes the market for the original, is independent of gender. 
Gender and copyright is too ambiguous and confusing Actual numbers

\begin{tabular}{|l|l|l|}
\hline & $\begin{array}{l}\text { No/No } \\
\text { Response }\end{array}$ & Yes \\
\hline Female & 28 & 5 \\
\hline Male & 26 & 3 \\
\hline
\end{tabular}

Percentages:

\begin{tabular}{|l|l|l|}
\hline & $\begin{array}{l}\text { No/No } \\
\text { Response }\end{array}$ & Yes \\
\hline Female & 84.8 & 15.2 \\
\hline Male & 89.7 & 10.3 \\
\hline
\end{tabular}

Pearson's Chi-squared test with Yates' continuity correction $\mathrm{X}$-squared $=0.0337, \mathrm{df}=1, \mathrm{p}$-value $=0.8543$

Thus, we conclude that gender and the belief that copyright laws are too ambiguous and confusing are independent.

Gender and whether must get permission/pay royalties to perform Actual numbers:

\begin{tabular}{|l|l|l|}
\hline & $\begin{array}{l}\text { No/No } \\
\text { Response }\end{array}$ & Yes \\
\hline Female & 26 & 7 \\
\hline Male & 18 & 11 \\
\hline
\end{tabular}

Percentages:

\begin{tabular}{|l|l|l|}
\hline & $\begin{array}{l}\text { No/No } \\
\text { Response }\end{array}$ & Yes \\
\hline Female & 78.8 & 21.2 \\
\hline Male & 62.1 & 37.9 \\
\hline
\end{tabular}

Pearson's Chi-squared test with Yates' continuity correction $\mathrm{X}$-squared $=1.3612, \mathrm{df}=1, \mathrm{p}$-value $=0.2433$

Thus, we conclude that gender is independent of believing that copyright laws suppress creativity. 
Gender and whether enforcement costs too much Actual numbers:

\begin{tabular}{|l|l|l|}
\hline & $\begin{array}{l}\text { No/No } \\
\text { Response }\end{array}$ & Yes \\
\hline Female & 32 & 1 \\
\hline Male & 28 & 1 \\
\hline
\end{tabular}

Percentages:

\begin{tabular}{|l|l|l|}
\hline & $\begin{array}{l}\text { No/No } \\
\text { Response }\end{array}$ & Yes \\
\hline Female & 97.0 & 3.0 \\
\hline Male & 96.6 & 3.4 \\
\hline
\end{tabular}

Pearson's Chi-squared test with Yates' continuity correction $\mathrm{X}$-squared $=0.3936, \mathrm{df}=1, \mathrm{p}$-value $=0.5304$

Thus, we conclude that believing that enforcement costs too much is independent of gender.

Gender and use is okay if not profiting from others' work Actual numbers:

\begin{tabular}{|l|l|l|}
\hline & $\begin{array}{l}\text { No/No } \\
\text { Response }\end{array}$ & Yes \\
\hline Female & 12 & 21 \\
\hline Male & 20 & 9 \\
\hline
\end{tabular}

Percentages:

\begin{tabular}{|l|l|l|}
\hline & $\begin{array}{l}\text { No/No } \\
\text { Response }\end{array}$ & Yes \\
\hline Female & 36.4 & 63.6 \\
\hline Male & 69.0 & 31.0 \\
\hline
\end{tabular}

Pearson's Chi-squared test with Yates' continuity correction $\mathrm{X}$-squared $=5.3287, \mathrm{df}=1, \mathrm{p}$-value $=0.02098$

Thus, we conclude that gender and whether someone believes use is okay if not profiting from others' work are strongly dependent. 
Gender and whether must credit original author Actual numbers:

\begin{tabular}{|l|l|l|}
\hline & $\begin{array}{l}\text { No/No } \\
\text { Response }\end{array}$ & Yes \\
\hline Female & 25 & 8 \\
\hline Male & 24 & 5 \\
\hline
\end{tabular}

Percentages:

\begin{tabular}{|l|l|l|}
\hline & $\begin{array}{l}\text { No/No } \\
\text { Response }\end{array}$ & Yes \\
\hline Female & 75.8 & 24.2 \\
\hline Male & 82.8 & 17.2 \\
\hline
\end{tabular}

Pearson's Chi-squared test with Yates' continuity correction $X$-squared $=0.1318, \mathrm{df}=1, \mathrm{p}$-value $=0.7166$

Thus, we conclude that whether someone believes they must credit the original author and their gender are independent.

Gender and parody is okay/not a violation Actual numbers:

\begin{tabular}{|l|l|l|}
\hline & $\begin{array}{l}\text { No/No } \\
\text { Response }\end{array}$ & Yes \\
\hline Female & 26 & 7 \\
\hline Male & 23 & 6 \\
\hline
\end{tabular}

Percentages:

\begin{tabular}{|l|l|l|}
\hline & $\begin{array}{l}\text { No/No } \\
\text { Response }\end{array}$ & Yes \\
\hline Female & 78.8 & 21.1 \\
\hline Male & 79.3 & 20.7 \\
\hline
\end{tabular}

Pearson's Chi-squared test with Yates' continuity correction $\mathrm{X}$-squared $=0.0688, \mathrm{df}=1, \mathrm{p}$-value $=0.7932$

Thus, we conclude that gender and whether someone believes parody is okay and not a violation are independent. 
Gender vs. can use only small snippet Actual numbers:

\begin{tabular}{|l|l|l|}
\hline & $\begin{array}{l}\text { No/No } \\
\text { Response }\end{array}$ & Yes \\
\hline Female & 29 & 4 \\
\hline Male & 26 & 3 \\
\hline
\end{tabular}

Percentages:

\begin{tabular}{|l|l|l|}
\hline & $\begin{array}{l}\text { No/No } \\
\text { Response }\end{array}$ & Yes \\
\hline Female & 87.9 & 12.1 \\
\hline Male & 89.7 & 10.3 \\
\hline
\end{tabular}

Pearson's Chi-squared test with Yates' continuity correction $\mathrm{X}$-squared $=0.033, \mathrm{df}=1, \mathrm{p}$-value $=0.8559$

Thus, we conclude that gender is independent of whether someone believes they can use only a small snippet.

Gender and use is okay if is for educational purpose Actual numbers:

\begin{tabular}{|l|l|l|}
\hline & $\begin{array}{l}\text { No/No } \\
\text { Response }\end{array}$ & Yes \\
\hline Female & 31 & 2 \\
\hline Male & 25 & 4 \\
\hline
\end{tabular}

Percentages:

\begin{tabular}{|l|l|l|}
\hline & $\begin{array}{l}\text { No/No } \\
\text { Response }\end{array}$ & Yes \\
\hline Female & 93.9 & 6.1 \\
\hline Male & 86.2 & 13.8 \\
\hline
\end{tabular}

Pearson's Chi-squared test with Yates' continuity correction $\mathrm{X}$-squared $=0.3565, \mathrm{df}=1, \mathrm{p}$-value $=0.5504$

Thus, whether someone believes it is okay to use someone else's work if it is for education purposes is independent of their gender. 
Gender and use for private entertainment or for group of friends is okay Actual numbers:

\begin{tabular}{|l|l|l|}
\hline & $\begin{array}{l}\text { No/No } \\
\text { Response }\end{array}$ & Yes \\
\hline Female & 25 & 8 \\
\hline Male & 27 & 2 \\
\hline
\end{tabular}

Percentages:

\begin{tabular}{|l|l|l|}
\hline & $\begin{array}{l}\text { No/No } \\
\text { Response }\end{array}$ & Yes \\
\hline Female & 75.8 & 24.2 \\
\hline Male & 26 & 6.9 \\
\hline
\end{tabular}

Pearson's Chi-squared test with Yates' continuity correction $\mathrm{X}$-squared $=2.2706, \mathrm{df}=1, \mathrm{p}$-value $=0.1318$

Thus, we conclude that whether someone believes use for private entertainment or for a group of friends is acceptable is independent of gender.

Gender and "I leave that to the lawyers"

Actual numbers:

\begin{tabular}{|l|l|l|}
\hline & $\begin{array}{l}\text { No/No } \\
\text { Response }\end{array}$ & Yes \\
\hline Female & 33 & 0 \\
\hline Male & 25 & 4 \\
\hline
\end{tabular}

Percentages:

\begin{tabular}{|l|l|l|}
\hline & $\begin{array}{l}\text { No/No } \\
\text { Response }\end{array}$ & Yes \\
\hline Female & 100 & 0 \\
\hline Male & 86.2 & 13.8 \\
\hline
\end{tabular}

Pearson's Chi-squared test with Yates' continuity correction

$\mathrm{X}$-squared $=2.8486, \mathrm{df}=1, \mathrm{p}$-value $=0.09145$

Thus, we conclude that whether someone's view of fair use definition is "I leave that to the lawyers" is weakly dependent on their gender. 
Gender and whether must get permission/pay royalties to perform Actual numbers:

\begin{tabular}{|l|l|l|}
\hline & $\begin{array}{l}\text { No/No } \\
\text { Response }\end{array}$ & Yes \\
\hline Female & 28 & 5 \\
\hline Male & 26 & 3 \\
\hline
\end{tabular}

Percentages:

\begin{tabular}{|l|l|l|}
\hline & $\begin{array}{l}\text { No/No } \\
\text { Response }\end{array}$ & Yes \\
\hline Female & 84.8 & 15.2 \\
\hline Male & 89.7 & 10.3 \\
\hline
\end{tabular}

Pearson's Chi-squared test with Yates' continuity correction $\mathrm{X}$-squared $=0.0337, \mathrm{df}=1, \mathrm{p}$-value $=0.8543$

Thus, we conclude that gender and whether someone believes fair use means that someone must get permission/pay a royalty perform are independent. 
